\title{
Dinoflagellate fossils: Geological and biological applications
}

\author{
Penaud Aurélie ${ }^{1,{ }^{*}}$, Hardy William ${ }^{1}$, Lambert Clément ${ }^{1}$, Marret Fabienne ${ }^{2}$, Masure Edwige ${ }^{3}$, \\ Servais Thomas ${ }^{4}$, Siano Raffaele ${ }^{5}$, Wary Mélanie ${ }^{6,7}$, Mertens Kenneth ${ }^{8}$
}

${ }^{1}$ UMR 6538 Géosciences Océan, IUEM, Université Brest, CNRS, 29280 Plouzané, France

2 Department of Geography and Planning, School of Environmental Sciences, University of Liverpool, L69 7ZT Liverpool, UK

${ }^{3}$ Centre de Recherche sur la Paléobiodiversité et les Paléoenvironnements, CR2P, UMR 7207, MNHN, CNRS, Sorbonne université, 4, place Jussieu, 75005 Paris, France

${ }^{4}$ CNRS UMR 8198 Evo-Eco-Paleo, Université Lille, 59000 Lille, France

${ }^{5}$ Ifremer, Centre de Brest, DYNECO PELAGOS, 29280 Plouzané, France

${ }^{6}$ UMR 5805 EPOC (Environnements et Paléoenvironnements Océaniques et Continentaux), Université Bordeaux, CNRS, EPHE, 33615 Pessac, France

${ }^{7}$ Institute of Environmental Science and Technology (ICTA), Universitat Autònoma de Barcelona, 08193

Bellaterra, Catalonia, Spain

${ }^{8}$ Ifremer, LER BO, Station de Biologie Marine, place de la Croix, BP 40537, 29185 Concarneau cedex, France

* Corresponding author : Aurélie Penaud, email address : aurelie.penaud@univ-brest.fr

\begin{abstract}
:
Dinoflagellates are part of the marine plankton and about 200 species produce a cyst (dinocyst) during their life cycle, these organic-walled sexually-produced cysts being fossilizable in sediments for hundreds of millions of years. Over the past 40-50 years, dinocysts have led to major advances on Mesozoic-Cenozoic research, in terms of biostratigraphy and paleogeogeography. Dinocyst taxonomy has then been continuously revised, with the tabulation being the main morphological link between living dinoflagellates and fossilized cysts. Over the Quaternary, and based on the principle of uniformitarianism (i.e. species ecology did not change through time), relationships between modern assemblages and present-day environmental factors controlling their distribution also allow for dinocystbased quantitative reconstructions derived from transfer function calculations. This paper presents a non-exhaustive review of the dinocyst literature allowing the reader to get a perspective about how they were discovered and defined, but also how they are applied in (paleo)ecological studies according to the timescale considered allowing then to provide useful insights into the future climate change and its associated ecological repercussions.
\end{abstract}

Keywords : Dinoflagellate, Cyst-motile stage relationship, Modern dinocyst distribution, Paleoecology, Biostratigraphy, Ancient DNA 


\section{Introduction}

Dinoflagellates are unusual eukaryotes in many ways and, according to morphology, fossil records, biomarkers and molecular phylogenies, their evolution and origin remain debated up to now. Dinoflagellates have been claimed to be plants (algae) by botanists and animals (protozoa) by zoologists and were classified as such during the $\mathrm{XIX}^{\text {th }}$ and early $\mathrm{XX}^{\text {th }}$ centuries. They are biflagellate marine and freshwater protists with vesiculated membranes belonging to the Alveolates and represent the only protist group to have both phototrophic and heterotrophic taxa. Alveolates are supposed to have diverged in the Neoproterozoic; dinoflagellates have been suggested to appear in the Paleozoic based on biomarker or biomolecular evidence, whereas fossil dinoflagellate cysts or dinocysts appear only in the Mesozoic.

Dinoflagellate cysts (cyst-motile stage relationships discussed in Chapter 1) can fossilize in sediments for hundreds of millions of years and have long been used across the MesozoicCenozoic timescale for biostratigraphical and paleogeographical studies (Chapter 2) as well as paleoceanographical studies (Chapters 3 and 4) including quantitative reconstructions (Chapter 3). To illustrate the potential of dinocysts in paleoceanographical studies, we focus on the last glacial period in the North Atlantic Ocean that constitutes one of the typical examples of enigmatic features of rapid climate variability (Chapter 4). Finally, the most recent evolution in Quaternary paleoecology is combining high resolution palynology (Chapter 5) with ancient DNA on historical time-scales (Chapter 6). The example is chosen from the Bay of Brest (northwestern France) with the estuarine environment of Daoulas that today records more and more intense toxic dinoflagellate blooms linked with the nutrient enrichment (eutrophication) of the aquatic system. 


\section{Importance of cyst-motile stage relationships for dinoflagellate taxonomy}

The existence of two life stages, respectively called the motile stage and the cyst stage, has caused the creation of separate biological and paleontological classification systems. The most recent version of the International Code of Nomenclature for algae, fungi and plants (ICN) stipulates that separate names are allowed for the fossil and living dinoflagellates (or cyst and motile stages, respectively; McNeill et al., 2012). Based on the configuration of the vesicles of the motile stage, the so-called tabulation, dinoflagellates were classified into 14 major orders: Gymnodiniales, Ptychodiscales, Suessiales, Gonyaulacales, Peridiniales, Nannoceratopsiales, Dinophysiales, Prorocentrales, Desmocapsales, Phytodiniales, Thoracosphaerales, Blastodiniales, Noctilucales and Syndiniales (Fensome et al., 1993). Several orders are not discussed here: Nannoceratopsiales are extinct and no cysts are known for some Blastodiniales, Desmocapsales, Noctilucales and Syndiniales.

Resting cysts are known to be produced during the sexual phase; Stosch (1964, 1965, 1972, 1973) indeed demonstrated that sexual processes lead to resting cyst formation in different marine and freshwater species. These sexually-produced cysts, usually organic-walled (dinosporin), can be distinguished from asexual cellulosic resting stages (ecdysal or pellicle cysts; e.g., Bravo and Figueroa, 2014), although a quite diversified set of composition exists for the cyst. Organic-walled cysts consist of a macromolecule, whose chemical composition in phototrophic dinoflagellates suggests a cellulose-like glucan, while heterotrophic forms produce a nitrogen-rich glycan (Bogus et al., 2014). These organic-walled cysts are fossilizable, thus commonly observed in the sedimentary archive, and are found within the Peridiniales, Gonyaulacales, Prorocentrales, Gymnodiniales, Thoracosphaerales (only Pentapharsodinium and Ensiculifera), Phytodiniales and perhaps Dinophysiales (see below). Calcareous cysts that have an inner organic lining are restricted to the Thoracosphaerales 
(Gottschling et al., 2012). Modern siliceous cysts are known only for Ceratium hirundinella (Chapman et al., 1982).

About $13-16 \%$ of dinoflagellates are known to produce resting cysts (Head, 1996). Since then, around 100 new cyst-motile stage relationships have been proposed. As there are now at least 2,294 species of dinoflagellates described (Gómez, 2012), adding these 100 new cystmotile stage relationships to the 260 listed by Head (1996), suggests that this percentage remains similar, and cyst-motile relationships have kept more or less in line with new species descriptions. However, the exact number still needs to be calculated since not only the new relationships are important, but previously documented cyst-motile stage relationships have been revised (e.g., Lewis et al., 2001) and synonymies between motile stages and cysts have changed (e.g., Gómez, 2012; Williams et al., 2017a). A detailed update of Head (1996) is imminent (Head, pers. comm.).

Also, at least 71 modern cysts have been shown to preserve in the fossil record (Zonneveld et al., 2013; Mudie et al., 2017), which is about a third of known cysts. In some orders of dinoflagellates, cysts are known for many genera, and it is likely that many more will be described in years to come. Within the Thoracosphaerales, many cysts have been described for many genera, particularly for Scrippsiella, Pentapharsodinium and Ensiculifera (e.g., Lewis, 1991, Kobayashi and Matsuoka, 1995), but also for Pfiesteriaceae such as Pfiesteria (e.g., Litaker et al., 2002) and the enigmatic benthic genus Bysmatrum (Limoges et al., 2015). The discovery of living cysts belonging to the Suessiales was exciting (Montresor et al., 1999). Previously, only long extinct species belonged to that order, and other suessioid cysts have since been described, particularly for the freshwater dinoflagellates (e.g., Calado and Moestrup, 2005; Hansen et al., 2007).

In other orders of dinoflagellates, resting cysts seem to be restricted to certain genera or subgenera. Within the Peridiniales, this is most notable for the genus Protoperidinium where 
many cysts are documented for species with a first apical paraplate that is ortho, while few cysts have been recorded for species with a first apical paraplate that is meta (e.g., a cyst is depicted by Nordli (1951) for Protoperidinium granii) or para (e.g., a cyst is recorded by Wall and Dale (1968) for Protoperidinium latissimum). Also within the Peridiniales, however, nearly all genera belonging to the diplopsalioideans seem to have cysts (e.g., Liu et al., 2015a). Within the Gonyaulacales, for some genera, resting cysts are undisputable, such as Gonyaulax, Lingulodinium and Protoceratium, whilst for others, no resting cysts have yet been recorded, such as for many planktonic (e.g., Ceratocorys, Goniodoma) and particularly benthic (e.g., Coolia, Gambierdiscus) species. Observations of resting cysts belonging to the gonyaulacoid genus Tripos (as Neoceratium; Gómez et al., 2010) are remarkable, and seem to suggest that these cysts have been overlooked, and might be fragile or short-lived, and hence not easy to discover. For the Gymnodiniales, resting cysts have been described for many genera such as Polykrikos, Gyrodinium, Gymnodinium, Barrufeta and Akashiwo (e.g., Matsuoka, 1988; Sampedro et al., 2011; Gu et al., 2015) but are not known for other resting cysts (e.g., Karenia, Takayama, Nematodinium). For the Phytodiniales, resting cysts have been recorded for several genera (e.g., Hemidinium, Spiniferodinium) but not for others (e.g., Hypnodinium, Manchudinium). It is remarkable that for some orders of dinoflagellates, no resting cysts have been recorded with certainty. This is particularly true for Dinophysiales where cysts have been observed but have to be treated with caution. These have never been observed to be formed in culture and have never been hatched (review by Reguera et al., 2012). Within the Prorocentrales, cyst observations within Prorocentrum remained long doubtful, but a recent study has unambiguously showed that cysts exist for the benthic species Prorocentrum leve (Mertens et al., 2017a). A major problem with cyst-motile stage relationships is that incubation and culturing experiments can never provide evidence that a particular motile stage of a species does not produce a cyst. Therefore, it is possible that, for 
some species, cyst production could have been switched off, or their biogeochemical pathways could have changed, during dinoflagellate evolution. For example, Ceratiaceae are recorded from Early to Late Cretaceous, and their gap in the fossil record at the end of Cretaceous may be explained by a transition from resistant dinosporin-based cysts to unpreservable siliceous/cellulosic resting cysts, present in extant Ceratiaceae (Wall and Evitt, 1975; Chapman et al., 1982; Gómez et al., 2010). It is hoped that genetic studies like gene expression ones might reveal such mechanisms. Another problem is that for many modern cyst species found in surface sediments, no motile stage is yet known (e.g., Melitasphaeridinium choanophorum; Price et al., 2017a). This is particularly true for oceanic species (Nematosphaeropsis, Impagidinium) which are rarely seen with cell contents and are difficult to hatch. Some species seem to be endemic and restricted in distribution and therefore the establishment of the cyst-theca relationship occurred only recently (Dapsilidinium pastielsii; Mertens et al., 2014).

Cyst morphology is generally species-specific. Within the Peridiniales, species are easily distinguished using cyst morphology (e.g., Wall and Dale, 1968; Harland, 1983), which has been thoroughly studied specifically for the spiny round brown cysts (Radi et al., 2013). For gonyaulacoids, cyst morphologies allow species identification particularly for Gonyaulax (e.g., Rochon et al., 2009). One gonyaulacoid exception is Alexandrium catenella and Alexandrium tamarense that have been related to the same cyst morphology (Fukuyo, 1985), while for other Alexandrium species, the cyst morphology is useful to separate different species (e.g., Bolch et al., 1991). Within Thoracosphaerales, cysts are also informative up to the species level (e.g., Lewis, 1991). An exception however exists with Scrippsiella trochoidea which was shown to exist out of several cryptic species with very similar morphologies of motile and cyst stages (Montresor et al., 2003), questioning what is the true Scrippsiella trochoidea (Zinssmeister et al., 2011). For some orders, cyst morphology is also 
helpful in generic classification. This is particularly true for the Peridiniales, where superficially similar species belonging to the genus Protoperidinium have such different cyst morphologies that they are classified within different cyst-based genera (e.g., Quinquecuspis, Trinovantedinium, Votadinium, Brigantedinium; Harland, 1983). First attempts to understand the combined evolution within Peridiniales suggest that molecular phylogenies reflect well the sections within Protoperidinium, as well as the related cyst-based genera (e.g., Matsuoka and Kawami, 2013; Gu et al., 2015; Mertens et al., 2017b). For the diplopsaloideans, cyst morphology is also genus-specific (e.g., Liu et al., 2015b), although nearly no cyst-based names have been erected (e.g., Matsuoka, 1988), presumably because these cysts are difficult to identify up to the genus or species level in the fossil record. Within Gonyaulacales, the motile-based genus Gonyaulax can be subdivided into different cyst-based genera (e.g., Spiniferites, Bitectatodinium, and Impagidinium), although molecular phylogenies are still in an early stage and need more sequences (Mertens et al., 2017c). Two issues with dual nomenclature in gonyaulacoids were recently identified. First, Mertens et al. (2017c) have shown that the motile species Gonyaulax baltica can be related to two cyst genera: Impagidinium and Spiniferites (heterospory). Second, Mertens et al. (2018) showed that the cyst Operculodinium can be related to two motile genera Protoceratium and Pentaplacodinium. These discrepancies between motile-based and cyst-based taxonomies are not easily resolved and have led to debates regarding dual nomenclature (Ellegaard et al., in press). Future morpho-molecular works will perhaps help resolve such issues. At higher taxonomic levels, it often becomes more difficult to evaluate the value of cysts. Indeed, in molecular phylogenies, affinities between genera and species are revealed with significant bootstrap support, and more basal nodes in phylogenies have often no significant bootstrap values (e.g., Daugbjerg et al., 2000; Saldarriaga et al., 2004). Concatenated phylogenies (e.g., Orr et al., 2012; Gottschling et al., 2012) and transcriptomics (e.g., Janouškovec et al., 2016; 
Price and Bhattacharya, 2017) can increase the support of these basal nodes, and are promising techniques to evaluate the classification proposed by Fensome et al. (1993). For instance, transcriptome-based phylogenetic trees of Janouškovec et al. (2016) suggest that a late acquisition of dinosterol in the dinoflagellate group is inconsistent with dinoflagellates as being the source of this biomarker in pre-Mesozoic strata. They proposed a revised model for the evolution of thecal tabulations, the monophyly of thecate dinoflagellates (Peridiniales, Gonyaulacales, Prorocentrales) and the paraphyly of athecate ones (Gymnodiniales).

\section{Dinocysts as powerful biostratigraphical proxies}

\section{Acritarchs and dinocysts}

Ehrenberg (1836) was the first author to recognize fossil dinoflagellate cysts in thin flakes of Cretaceous flints. He observed tabulation and flagellar furrows and compared those to the living planktonic genus Peridinium and erected a new species Peridinium pyrophorum (now Palaeoperidinium pyrophorum). He also observed spiny bodies bearing variable spine morphologies, and considered these to be Desmids (e.g. extant freshwater green algae, Zygnematophyceae) and described Xanthidium ramosum (now Spiniferites ramosus). The term "Xanthidia" named all these spiny bodies during almost a century. Deane (1845) and Reinsch (1905) suggested that "Xanthidia" were not Desmids and Wetzel (1933) erected the genus Hystrichosphaera with both $H$. furcata and $H$. ramosa as type species. Nevertheless, their affinity remained unknown and Deflandre (1936) regarded Hystrichospheres as Incertae sedis. As "Xanthidia", the term "Hystrichosphere" became popular and was used for spiny bodies until 1960. The first clear interpretation of the relation between dinoflagellate thecae and cysts and the demonstration that hystrichospheres are dinoflagellate cysts were suggested through meticulous morphological comparison on 119 genera (Evitt, 1961). He observed that the openings of dinoflagellate cysts are regular in form and position and correspond to a plate 
or group of plates. He created the name archeopyle (Evitt, 1961) to define the angular germinal opening of cysts. By the precise study of variable hystrichosphere processes, he showed that their number and size are related to the number and size of thecae plates. These hystrichospheres have indeed to be interpreted as planozygotes formed within thecae.

From 1964 to 2012, Arpylorus antiquus (Calandra, 1964) was considered by many as the first non-controversial dinocyst described from the Silurian of southern Tunisia. The common dinoflagellate tabulation was described in the folded vesicle through the quadrangular form of the aperture split into plate-like fragments, and these elements were used to interpret $A$. antiquus as a dinocyst (Evitt and Davidson, 1964; Sarjeant, 1978; Stover and Evitt, 1978; Lentin and Williams, 1981). Nevertheless, many researchers questioned the absence of cingulum and sulcus marks (Bujak and Williams, 1981; Bujak and Davies, 1983; Evitt, 1985). Le Herissé et al. (2012) studied the type material and concluded that A. antiquus is not a dinocyst. Indeed, the large development of a fine membrane at the periphery of vesicles, and the composition of the wall (analyzed with a Fourier transform infrared (FTIR) microspectroscopy) made of a biopolymer not consistent with dinosporin or dinosterane, led these authors to conclude that $A$. antiquus would rather represent a storage structure produced by invertebrates such as eurypterids (“sea scorpions”).

Much later, during the Triassic, a time of appearance and diversification of many fossil groups, organic-walled microfossils undoubtedly related to dinocysts appeared in the Ladinian, Middle Triassic, around 240 Ma (Fensome et al., 1996). Dinoflagellates evolved rapidly to fill the niches left vacant after the Permian-Triassic mass extinctions and the radiation of dinoflagellates during the Middle Triassic to the Middle Jurassic has been a real evolutionary process (Fensome et al., 1996). Mesozoic explosion and diversification of the overall species abundances and genera were linked to the increasing global sea level resulting in large number of shallow coastal shelves (MacRae et al., 1996). The earliest dinocyst forms 
wore numerous latitudinal paraplate series. The fossil record indicates a general trend in the reduction of series, and the main extant counterpart orders, Gonyaulacales and Peridiniales, appeared during the Early Jurassic.

However, although microfossils with all morphological characters of dinocysts only appear in the early Mesozoic, many Paleozoic palynomorphs, mostly assigned to the acritarchs, have strong morphological similarities with dinocysts, but also similar paleogeographical or paleoecological distribution patterns. Indeed, Evitt (1963) created the term acritarchs for all those "hystrichospheres" that could not be attributed to dinocysts, i.e. all organic-walled microfossils displaying splits or simple circular openings, but without groove marks and with morphologies different from those of dinoflagellates and other living organisms (Figure 1a). The acritarchs are, by definition, of unknown origin (Incertae sedis), known from the Proterozoic and throughout the Phanerozoic. Acritarchs probably include a high variety of biological groups, and not all of them should be considered as cysts of microphytoplankton. In addition, not all acritarchs are marine. Simple acritarchs have been found since the Archaean 3,200 Ma (Javaux et al., 2010) and are most probably not related to dinocysts. A study of openings and process distributions in Early Paleozoic acritarchs led Lister (1970) and Bujak and Williams (1981) to suggest that some of these acritarchs could be dinocysts (e.g., Cymbosphaeridium). Organisms with probable dinoflagellate affinity have been reported from Neoproterozoic (i.e. 900 to 800 Ma, Butterfield and Rainbird, 1998) and Leppig and Montenari (2000) subsequently suggested the term "protodinoflagellates". Galeate acritarchs (Servais and Eiserhardt, 1995), from the Cambrian-Ordovician transition, are interpreted as resting cysts of microorganisms similar to dinoflagellates (Servais et al., 2004): similar size ranges and process morphologies, the presence of an archeopyle-like opening and of a tabulation-like pattern on the vesicle wall, strongly resemble those of dinocysts (Figure 1b). In terms of biomarker studies, the presence of dinosteranes 4-methyl-24-ethylcholestane, 
commonly associated with dinoflagellates cysts, in Precambrian, Cambrian and Paleozoic kerogens led Moldowan et al. (1996), Moldowan and Talyzina (1998) and Talyzina et al. (2000), to propose that some acritarchs were related to dinoflagellates, originating from late Precambrian, and were probably already common in the early Paleozoic.

\section{Taxonomic tools and dinocyst classification for biostratigraphy}

Useful taxonomic tools have been developed, known as the Eisenack Catalogs (Eisenack and Klement, 1964; Eisenack and Kjellström, 1972), and then followed by new series of five volumes (e.g., Fensome et al., 1991). Indexation of fossil dinoflagellates at generic, specific and intraspecific level has been compiled in the Lentin and Williams Indexes by Lentin and Williams (1973, 1993), followed by Fensome and Williams (2004) and Williams et al. (2017b). These authors developed database systems: Dinoflaj1 (based on the Lentin and Williams Index of fossil dinoflagellates 2004 Edition; Fensome and Williams, 2004), Dinoflaj2 (Fensome et al., 2008) and Dinoflaj3 (Williams et al., 2017b). In addition, a compilation of genera based on archeopyle types was developed by Stover and Evitt (1978), and guides with new holotype illustrations and determination keys were published by Jan du Chêne et al. (1986) and Fauconnier et al. (2002). During the 1960s, authors attempted to merge classification of fossil taxa with the biological classification of modern dinoflagellates (Eisenack and Klement, 1964; Norris and Sarjeant, 1965; Vozzhennikova, 1967), taking into account earlier morphological concepts (proximate, chorate, cavate cysts, with archeopyle types). Evitt suggested that the fundamental building blocks of classification of fossil dinoflagellates are the tabulation; his concepts strongly influenced subsequent authors (Wall and Dale, 1968; Norris, 1978; Harland, 1982). A progressive increase in the phylogenetic component has been developed successively by Wall and Dale (1968), Williams (1977), and Dörhöfer and Davies (1980). Eaton (1980) and Taylor (1980) suggested two new systems to 
explain relationships and evolution within Peridiniales. From a primitive model (Taylor, 1980) and the migration of plates, Evitt (1985) suggested hypothesized derivation of quinqueform and sexiform tabulations within Gonyaulacacea. A unified classification of fossil and modern dinoflagellates has been established by Fensome et al. (1993).

Before World War II, pioneers (Deflandre, 1937, 1938; Eisenack, 1938) produced substantial publications concerning Cretaceous and Jurassic dinocysts. These microfossils have subsequently been used in petroleum exploration, and a significant number of publications were dedicated to the description of new taxa (Deflandre and Cookson 1955; Cookson and Eisenack, 1958, 1960), and to dinocyst assemblages related to stages and stratotypes (Foucher, 1979, 1985; Sarjeant, 1979; Davey and Verdier, 1973). First dinocyst charts, based on outcrop samples, were published during the 1950s, and biostratigraphy was successfully used for years by combining dinocyst data with data from ammonites (Sarjeant, 1965; Monteil, 1992a, b, 1993), foraminifera (Gruas-Cavagnetto et al., 1988, Powell, 1992a), calpionelles and nannofossils (Van Hinte, 1976a, b; Vail et al., 1977; Hardenbol and Berggren, 1978). Zonations, First and Last Appearance Data (FAD and LAD), were indeed used to produce stratigraphically robust basin-wide correlations for distinct events. A synthesis was first published for the Jurassic by Woollam and Riding (1983), and then for Mesozoic and Cenozoic timescales (Williams and Bujak, 1986; Powell, 1992b; Williams et al., 1993). For the northern hemisphere, two paleo-provinces have been reported, the tethysian and boreal domains; few dinoflagellate biozonations can thus be considered for large areas during the Cretaceous. For the southern hemisphere, a biostratigraphical synthesis was published by Helby et al. (1987) and Williams et al. (2004). Haq et al. (1987) also provided a Mesozoic and Cenozoic chart with microfossil biozones and dinoflagellate bio-horizons, through third order stratigraphic sequences. Sedimentologists and stratigraphers then built, for the Mesozoic and Cenozoic Sequence Stratigraphy of European Basins Project, a documented 
chronostratigraphy and outcrop record of depositional sequences calibrated across a large number of stratotypes (de Graciansky et al., 1999; Fensome et al., 2009). The Geologic TimeScale (GTS) Foundation provides information about dinoflagellate and acritarch FAD and LAD, as well as for other microfossils with standard chronostratigraphy (Ogg et al., 2008). Also, regarding more specifically the Cenozoic interval, typical Paleogeone dinocysts indicative of environmental conditions were compiled in Pross and Brinkhuis (2005). Paleocene and Eocene periods often include discussions on the specific Paleocene Eocene Thermal Maximum (PETM) event, representing a phase of global warming with massive $\mathrm{CO}_{2}$ inputs into the climate system, then implying extreme ecosystem variability (e.g., Frieling et al., 2018). Dinocyst stratigraphy for the Neogene in northern latitudes, and more precisely for the Oligocene-Miocene, is discussed in Schreck et al. (2017) and Bijl et al. (2018), respectively. Also, phase relationships between climate forcing and paleoecological responses across the Pliocene (De Schepper et al., 2015), Plio-Pleistocene climate transition (Hennissen et al., 2016), or Pleistocene glacial-interglacial stages (Donders et al., 2018) have also recently been discussed even if ecological optima of extinct species are not always well known, challenging the use of quantitative sea-surface reconstructions (cf. following chapter 3 of this manuscript). Indeed, although some species ecology has remained similar through the Neogene, especially across the Miocene and Pliocene (e.g., De Schepper et al., 2015; Hennissen et al., 2016; Schreck et al., 2017), dinocyst assemblages do not always find analogues in modern sediments. Across the Paleogene-Neogene timescale, dinocyst-based interpretations then often remain qualitative, but paleohydrological reconstructions on the preQuaternary period are tentatively calibrated through crossed geochemical-palynological information allowing for instance to infer temperature ranges for extinct taxa (e.g., Schreck et al., 2017; Frieling and Sluijs, 2018). 


\section{Modern dinocyst distribution and transfer function approaches}

The use of dinocysts as a proxy for Quaternary paleoclimate and paleoceanographic reconstructions is based on the principle of uniformitarianism, i.e. species ecology did not change through the Quaternary timescale. This fundamental concept is based on relationships between dinocyst assemblages and environmental factors controlling their distribution (e.g., Marret and Zonneveld, 2003; Zonneveld et al., 2013), i.e. between modern assemblages from core tops (or first centimeter of interface cores) and modern-day observations (instrumental data of sea-surface conditions). This step is a pre-requisite for quantitative reconstructions derived from transfer function calculations (e.g., Guiot and de Vernal, 2007).

\section{Worldwide dinocyst distribution in modern sediments}

The modern distribution and the taxonomy inventory of modern dinocyst species have been well documented through regional in situ studies of sediment traps and/or surface sediment samples since the 1960-70s (e.g., Wall, 1965; Wall et al., 1977; Williams, 1971; Harland, 1983, Turon, 1984; Dodge and Harland, 1991; Marret, 1994; Marret and de Vernal, 1997; Rochon et al., 1999; Zonneveld et al., 2001; Radi and de Vernal, 2004; Pospelova et al., 2005; Holzwarth et al., 2007; Bouimetarhan et al., 2009; Price and Pospelova, 2011; Limoges et al., 2013; Price et al., 2016; Mudie et al., 2017). Several of these studies constituted the basis for the first global Atlas of Recent dinoflagellate cyst distribution (835 modern assemblages), depicting worldwide distribution of 61 species (Marret and Zonneveld, 2003). An updated version then included 71 taxa in 2,405 samples (Zonneveld et al., 2013; Figure 2). A regional Atlas from the Marmara Sea to the Caspian Sea (Mudie et al., 2017; Figure 2) has enabled to further extend our knowledge on the ecological/environmental affinities of most of the dinocyst species routinely used for paleoceanographic investigations. However, gaps remain, 
in particular in pelagic regions of the Pacific, Indian and Southern oceans (Figure 2). Despite this incomplete coverage, worldwide modern dinocyst distribution highlights strong relationships between taxa and specific sea-surface conditions, and allows for a better understanding of ecological affinities of several dinocysts. Such atlases also point to the large contrasts between: i) cosmopolitan taxa with large environmental tolerances (i.e. found in most study sites), such as Brigantedinium spp. and Operculodinium centrocarpum sensu Wall and Dale 1966 (also Spiniferites ramosus or Impagidinium aculeatum; Figure 3) and ii) inversely, species with a narrow distribution (i.e. restricted to specific surface conditions), such as Islandinium minutum and Selenopemphix antarctica (Figure 3). Furthermore, the highest taxa diversity observed in the northern hemisphere, especially around $60-65^{\circ} \mathrm{N}$ with more than 70 taxa per assemblage (Figure 3), represents a considerable strength for the dinocyst proxy regarding paleoceanographic reconstructions, such as for diatoms, since these regions are often characterized by low foraminiferal diversity or even monospecific assemblages, with carbonates being partly dissolved under low sea-surface temperatures (Kucera, 2007; Eynaud, 2011; Manno and Pavlov, 2014).

\section{Dinocyst-based Modern Analogue Technique}

Paleoceanographic transfer functions were first developed for foraminiferal and radiolarian assemblages, using Q-mode factors, which allow grouping species according to specific water mass conditions (Imbrie and Kipp, 1971), and then linearly linking these groups to seasurface conditions. However, unimodal response curves between a specific taxon and a specific hydrological parameter cannot be established (Marret and Zonneveld, 2003; Zonneveld et al., 2013), due to the complex ecology and/or large environmental tolerance for some dinocyst taxa and restricted distribution for others. Instead, the Modern Analogue Technique (MAT) was first developed (Hutson, 1980; Prentice, 1980) and applied in 
palynology to pollen assemblages (Guiot, 1990). Dinocyst assemblages have then also proven to be an advantageous tool to quantitatively assess sea-surface conditions (e.g., de Vernal et al., 1993, 2001, 2005, 2013a, b; Guiot and de Vernal, 2007, 2011; Radi and de Vernal, 2008), even if some critics argued for the large uncertainties in reconstructing summer temperature and sea ice cover also questioning the non-independency of winter temperature and salinity (Telford et al., 2004; Telford and Birks, 2005, 2009, 2011; Telford, 2006). In contrast to the Q-mode factor transfer function, the MAT estimates conditions within the range of the observed oceanographic dataset. This method assumes that modern dinocyst assemblages analyzed in bottom sediments are linked to the overlying oceanographic conditions. Modern oceanographic conditions such as annual and seasonal sea-surface temperature (SST) and salinity (SSS), duration of the sea-ice cover (SIC) and Net Primary Productivity (NPP), are thought to be the predominant primary factors controlling dinoflagellate populations. Observed measurements are then extracted from the World Ocean Atlas, National Snow and Ice Data Center and NASA's Ocean's Color space programs for sea-surface conditions (Table 1). The MAT is based on a similarity matrix, and the statistical distance between the fossil analyzed and all modern analogues existing in the dinocyst database (Table 2) determines the reconstruction of the sea-surface conditions (Guiot and de Vernal, 2007).

Currently, three calibrated modern dinocyst databases can be used (Figure 4). Each of these dinocyst databases encompasses sediment samples that were processed with the same laboratory protocol (i.e. standardized palynological treatment, de Vernal et al., 1999; and $\begin{array}{llll}\text { Rochon } & \text { et } & \text { al., } & \text { hittp://www.epoc.u- }\end{array}$ bordeaux.fr/index.php?lang=fr\&page=eq_paleo_pollens) and with homogenized taxonomy (Fensome and Williams, 2004; Fensome et al., 2008, 2009). The current largest database, from the Northern Hemisphere, includes 1,492 sites (de Vernal et al., 2013a); the second one, mostly located between $30^{\circ} \mathrm{N}$ and $50^{\circ} \mathrm{S}$, includes 237 sites (Marret et al., 2008; Hardy et al., 
2018); and the third one, from the Southern Ocean, comprises 343 sites (Marret et al., 2001; Esper and Zonneveld, 2002; Crouch et al., 2010; Verleye and Louwye, 2010; Prebble et al., 2013). A small database is currently developed in the Black Sea region (Mudie et al., 2017) but has not yet been tested for past sea-surface reconstructions. In order to investigate and then validate the sensitivity of dinocyst assemblages to various marine surface environmental settings, multivariate analyses are routinely conducted, in particular Canonical Correspondence Analysis (CCA; de Vernal et al., 2001; Marret et al., 2008; de Vernal et al., 2013a). This method highlights the taxonomic statistical distribution shaped by the affinity of some groups of species with predefined environmental parameters (Figure 5). For example, SIC (expressed in months.year ${ }^{-1}$ ) strongly determines the distribution and abundances of Islandinium? cezare, Islandinium minutum, Impagidinium pallidum and Islandinium brevispinosum in the Arctic Ocean.

Although chosen environmental parameters (SIC, SSS, SST and NPP) control most of the modern assemblage variability, the CCA analysis does not evidence sometimes an obvious link between species and abiotic factors. This probably suggests that other variables are not yet taken into account, such as turbulence, light availability, for quantitative reconstructions, and may imply to add such information in the environmental dataset. This has been recently proposed for instance to discuss and quantify colder water involved in upwelling cell mechanisms along the western African margin by defining an upwelling index using local SST anomalies (SST at the local level compared with SST average at the regional latitudinal level) (Hardy et al., 2018). Also, other data derived from abiotic parameters could be added in the environmental dataset such as seasonality in SST, SSS or NPP. Finally, a wider range of abiotic parameters are also available within the World Ocean Atlas, including water density, dissolved oxygen, oxygen saturation and abiotic nutrient concentration, and could be tested through CCA analyses. 


\section{Paleoceanographic reconstructions for the last glacial cycle in the North Atlantic}

\section{The last glacial period}

The last glacial was punctuated by rapid climate oscillations between cold (stadial) and warm (interstadial) atmospheric phases, known as the Dansgaard-Oeschger events (Dansgaard et al., 1993). The transition from stadial to interstadial phases is characterized by an abrupt warming of several degrees (up to $16^{\circ} \mathrm{C}$ ) in a few centuries (Kindler et al., 2014). These oscillations are thought to be linked to changes in the North Atlantic Ocean circulation and cryosphere dynamics. Interstadials are marked by a circulation pattern close to that of the present-day, i.e. a relatively active ocean circulation bringing warmth from low to high latitudes through a strong northward flow of warm surface waters by the Gulf Stream and its northward extensions (e.g., Rahmstorf, 2002). Stadials are associated with iceberg delivery resulting from the collapse of the northern hemisphere ice-sheets (e.g., Bond and Lotti, 1995). These surges appear similar, but occurred with a larger and wider extent, than the increasingly recurrent iceberg calving episodes occurring nowadays around Antarctica (e.g., Tollefson, 2017). They are thought to be responsible for the coeval slowdown of the North Atlantic Ocean circulation (e.g., Rahmstorf, 2002). The most extreme iceberg calving episodes, whose influence reached latitudes as low as ca. $36^{\circ} \mathrm{N}$ (e.g., Cacho et al., 2001; Eynaud et al., 2009), are referred to as Heinrich events (Heinrich, 1988). These recurring climate changes, likely initiated in the high latitudes of the North Atlantic, thus also directly affected the mid and low latitudes of this basin. Through coupled ocean-atmosphere-cryosphere teleconnections, they also had worldwide repercussions imprinted as millennial oscillations of various components of the climate system and expressed at widespread locations, such as atmospheric temperatures in Antarctica, East Asian monsoon intensity, or North Pacific upwelling activity 
(e.g., Voelker, 2002). A huge effort has been undertaken through numerous sedimentological, micropaleontological, palynological, and geochemical studies of last glacial sedimentary archives to explore the underlying ocean-cryosphere-atmosphere-biosphere relationships and tentatively disentangle causal and consequential mechanisms.

\section{Sea-surface temperature and salinity information}

Dinocyst-based studies conducted in the North Atlantic Ocean and adjacent seas have contributed to shed significant light on oceanic-climatic coupled processes (e.g., cores and data in Figures 6 and 7). In the northeastern Atlantic Ocean (e.g., Zaragosi et al., 2001; Eynaud et al., 2012), along the path of the Gulf Stream extensions, millennial to inframillennial stadial/interstadial shifts in ocean circulation were evidenced. Interstadials appear there to be characterized by the substantial influence of the warm northward inflow of surface waters from the Gulf Stream extensions. Indeed, core MD95-2002 (Bay of Biscay) allows to evidence higher SST (Eynaud et al., 2012) and higher abundances of Operculodinium centrocarpum sensu Wall and Dale 1966 (Figure 7b), whose modern distribution is tightly linked to the Gulf Stream northward extension pathways (e.g., Harland, 1983; Rochon et al., 1999), and conversely during stadials characterized by the southward migration of cold polar surface waters and increasing percentages of B. tepikiense (Figure 7b). The influence of the iceberg delivery was also detected on the eastern side of the North Atlantic through SSS

reconstructions that proved useful in tracking freshwater inputs resulting from both the melting of icebergs and European ice-sheets as well as the subsequent run-off that occurred on the Celtic margin (i.e. as evidenced through low SSS during stadials at site MD95-2002; Eynaud et al., 2012; Figure 7b'). In the subpolar northwestern Atlantic and Labrador Sea, SST and SSS reconstructions also enabled to evidence severe cooling and freshening of surface 
waters that occurred during Heinrich events in response to iceberg surges (de Vernal and Hillaire-Marcel, 2000; Hillaire-Marcel and de Vernal, 2008).

Combined to seasonal SST contrasts, SSS reconstructions in the subpolar northeastern Atlantic Ocean and southern Norwegian Sea furthermore provided a valuable way to infer variations in the stratification of the upper water column. There, during stadials, stronger seasonal SST contrasts associated to the lower salinity surface layer suggest an increase in the stratification of the upper water column. This is materialized by a lower thermal inertia of the fresher surface layer in response to the coeval slowdown of the North Atlantic Ocean circulation (i.e. decreasing influence of the warm and salty surface waters of the Gulf Stream extensions) and concomitant meltwater inputs associated with the iceberg delivery (Zumaque et al., 2012; Wary et al., 2015, 2016, 2017). In the southern Norwegian Sea (core MD992285), this interpretation was qualitatively supported by the concomitant higher abundances of B. tepikiense (Figure 7a), a taxon which presents a strong affinity for stratified surface waters associated with high seasonal contrasts (Rochon et al., 1999). Significant percentages of B. tepikiense also enabled to track the influence of Heinrich events as south as the southern Portugal (Turon et al., 2003; Penaud et al., 2011; core SU-8118, Figure 7c). Also, even if not significant in Gulf of Cádiz assemblages (core MD99-2339), B. tepikiense percentages summed with those of Spiniferites elongatus, Nematosphaeropsis labyrinthus, cysts of Pentapharsodinium dalei and Spiniferites lazus, allowed to detect the Heinrich event impact in subtropical northeastern Atlantic waters by the establishment of a qualitative paleothermometer (cf. lower Warm/Cold ratio obvious during Heinrich events in Figure 7d; Penaud et al., 2016). 


\section{Primary productivity changes}

In the intertropical area, primary productivity changes are related to wind stress changes and the complex interplay between ocean current reorganization and upwelling cell dynamics, as well as to river discharges and associated nutrient inputs. Productivity regimes are crucial to reconstruct through time since they represent an additional mechanism to the physicochemical carbon dioxide ocean-atmosphere exchanges, necessary to understand the carbon cycle that also involves the biological pump. Dinocyst-based quantitative studies have provided valuable information regarding productivity in the Congo Basin (Hardy et al., 2018, reconstructions made with the revised $n=208$ tropical Atlantic database published in Marret et al., 2008, Figure 4) as well as in the NE subtropical Ocean (Penaud et al., 2016, Figure 7d': reconstructions made with the $\mathrm{n}=1492$ Northern Hemisphere database published in de Vernal et al., 2013a, Figure 4). Today, proxies used for assessing primary productivity changes in the intertropical area are mainly represented by Total Organic Carbon, planktonic $\delta^{13} \mathrm{C}$, and/or Biogenic Silica. However, calcareous and/or siliceous microfossils are extremely sensitive to dissolution through $\mathrm{pH}$ and temperature changes in the water column (e.g., Takahashi and Honjo, 1981; Barker et al., 2005; Barker, 2016; Charrieau et al., 2018), while organic-walled dinocysts are immune to the effect of dissolution, being more subject to oxidation issues (Zonneveld et al., 1997; Gray et al., 2017). Dinocyst-derived reconstructions of past primary productivity changes therefore provide one of the most significant observations in the intertropical area.

Considering the last glacial cycle and its recurring millennial climate changes, dinocyst analyses carried out in subtropical to tropical North Atlantic latitudes shed light on significant paleohydrological changes from the western (Vink et al., 2001; Gonzáles et al., 2008) to the eastern Atlantic margins (southern Portugal: Turon et al., 2003; Eynaud et al., 2000; Penaud et al., 2011; western African margin: Marret and Turon, 1994; Marret et al., 2008; Holzwarth 
et al., 2010; Kim et al., 2010; Penaud et al., 2010, 2011, 2016; Hardy et al., 2016, 2018). Studies pointed to higher primary productivity conditions during glacial periods, and especially during stadials, as a result of increasing upwelling activity. This can be evidenced through increasing abundances of heterotroph dinocysts (mainly Brigantedinium spp.) as depicted by the Heterotroph/Autotroph ration in Figure 7c' (core SU-8118), and conversely during interstadials (i.e. enhanced stratification related to stronger continental freshwater discharges and/or upwelling relaxation). In the Gulf of Cádiz, increasing annual productivity during the glacial period (core MD99-2339, Figure 7d'), has been related to frontal system reorganizations within the Gulf of Cádiz resulting in local upwelling cells, especially during Heinrich events.

\section{Past sea ice cover in the northern Hemisphere}

Although sea ice is a parameter difficult to assess with paleoproxies (cf. de Vernal et al., 2013b), dinocysts offer the unique opportunity to get both qualitative indicators of sea ice (related to particular individual species, such as Islandinium minutum, whose highest abundances are found in cold polar waters seasonally covered with sea ice; Radi et al., 2013) and quantitative estimations of SIC duration and concentration (e.g., de Vernal et al., 2013a,b). Dinocyst data thus represent a valuable way to picture changes in sea-ice cover associated with the glacial millennial timescale variability, allowing to evidence significant SIC durations associated with the severe cooling recorded during Heinrich events in the subpolar northwestern Atlantic and Labrador Sea (de Vernal and Hillaire-Marcel, 2000; Hillaire-Marcel and de Vernal, 2008), as well as in the subpolar northeastern Atlantic (Caulle et al., 2013) and in the Bay of Biscay (Zaragosi et al., 2001; Auffret et al., 2002; Eynaud et al., 2012). In the Norwegian Sea, they have in contrast depicted a paradoxical pattern of seasurface conditions, usually uncaptured or challenged by interpretations derived from the most 
commonly used planktonic foraminiferal data (e.g. Dokken and Jansen, 1999; Rasmussen and Thomsen, 2004; Dokken et al., 2013), where cold stadials are marked by warmer sea-surface conditions and reduced SIC (Eynaud et al., 2002; Wary et al., 2017a,b; cf. core MD99-2285 for the southern Norwegian Sea, Figure7a'). They have equally denoted a similar atypical pattern over the whole Nordic Seas during the LGM (de Vernal et al., 2005), pointing out here again discrepancies between different proxies of sea-surface conditions (de Vernal et al., 2006) that were also reported in other multiproxy studies (e.g., Penaud et al., 2011; Eynaud et al., 2012). In most cases, these discrepancies have been suggested to likely result from differences in ecological strategies between producers (e.g., de Vernal et al., 2006; Wary et al., 2015, 2017a). Dinoflagellates, as well as coccolithophorids or diatoms, are mostly restricted to the uppermost 50 meters of the water column (e.g. Sarjeant, 1974). In contrast, the symbiont-free planktonic foraminiferal taxa composing assemblages of these area and period have the ability to adapt their depth habitat and migrate deeper (e.g., Schiebel et al., 2001), especially if surface conditions are not favorable to their development such as the low SSS that prevailed in this basin during these periods. Taphonomic biases related to preferential allochtonous advection of smaller and lighter planktonic remains (such as dinocysts) could also be implied (e.g., de Vernal et al., 2006). Even if unlikely in the case of the glacial Nordic Seas (Eynaud et al., 2002; Wary et al., 2016), such biases (as well as others related to seasonality of the growth season and/or interannual variability; e.g., de Vernal et al., 2005; Penaud et al., 2010) must always be kept in mind when using dinocysts in paleoceanographic studies.

\section{Pre-Quaternary dinocysts as erosion tracers}

From another point of view, advection of allochtonous dinocysts may provide valuable insights in the framework of paleo-reconstructions. In the case of the last glacial rapid 
variability, pre-Quaternary dinocysts, absent in most surface sediments from the North Atlantic but encountered in continental rocks overlaid by ice-sheets during the last glacial period, were used to track the geographical origin of icebergs during Heinrich events (Rahman, 1995). Maximal fluxes of these reworked palynomorphs, sometimes illustrated through high values of the "pre-Quaternary versus modern dinocysts" ratio or of preQuaternary cyst concentrations, were correlated to Heinrich event iceberg surges in the Labrador Sea (Gibb et al., 2014), while on the Celtic Margin and in the southern Norwegian Sea, they were attributed to intense melting and subsequent freshwater inputs from proximal ice-sheets (Zaragosi et al., 2001; Eynaud et al., 2007; Penaud et al., 2009; Wary et al., 2018). The highest values of pre-Quaternary cyst concentrations at the beginning of Heinrich event 1 are coeval with very low SSS values, thus depicting strong glacio-fluvial inputs from the European ice-sheets at that time (core MD95-2002, Figure 7b'). On the Celtic margin, which is located at the outlet of the Manche paleoriver, such interpretation was supported by concomitant high relative abundances of L. machaerophorum, often found near river mouths (e.g., Zonneveld et al., 2013; maximal percentages recorded today in southern Portugal and in the Gulf of Cádiz, Figures 7c and 7d), and high concentrations of coenobia of the freshwater microalgae Pediastrum spp. (Zaragosi et al., 2001; Auffret et al., 2002; Eynaud et al., 2007; Penaud et al., 2009). 


\section{Dinocyst-based paleoecological reconstructions on}

\section{coastal eutrophicated areas}

Moving from the oceanic domain to littoral environments, coastal and estuarine areas are constantly evolving, shaped by natural dynamic agents and anthropogenic impacts. Since the 1980s, international efforts have been undertaken to evaluate the magnitude and severity of present changes occurring along world's coastal areas. Resulting assessments pointed to a generalized disturbance of all coastal areas, whatever the oceans or seas they border (e.g., Tilman et al., 1994; Rabalais et al., 2009; IPCC, 2014). These changes are particularly relevant to shoreline development, surface water quality (i.e. temperature, salinity, nutrient concentration, industrial pollution) and marine organisms (i.e. biodiversity changes, invasive species). Due to increasing urbanization and agriculture growth, nutrient pollution has become a major concern in many coastal regions (e.g., Carpenter et al., 1998; Rabalais, 2002; Price et al., 2017b). For example, over $65 \%$ of US estuaries are considered as moderately to highly eutrophicated (Bricker et al., 2008). The effect of soil fertilization on the composition and structure of microbial coastal communities is indeed one of the major topics of presentday environmental sciences, taking into account that changes in temperature, moisture or nutrient rates are assumed to greatly affect biodiversity over many trophic levels (Diaz and Rosenberg, 2008). The currently accepted definition of eutrophication by Nixon (1995) is: « the process of increased organic enrichment of an ecosystem, generally through increased nutrient inputs ». Initially used to designate the natural nutrient enrichment, the term has recently been used to refer to human influences accelerating eutrophication of rivers, estuaries, or marine waters. Sources of anthropogenic activities include the leaching of agricultural fertilizers, land run off, sewage inputs, combustion of fossil fuels and nutrient excess from aquaculture (Glibert et al., 2005; Smayda, 2008). Human activities indeed 
contribute to the acceleration of nutrient enrichment over the last century with increased nitrogen and phosphorus inputs, thereby altering phytoplankton production and community structuring (e.g., Turner and Rabalais, 1994; Glasgow and Burkholder, 2000; Anderson et al., 2008).

Dinocysts are known to reflect anthropogenic changes and few studies have tried to link dinocyst distribution pattern to different pollution types. Most studies focused on the effect of nutrient enrichment on the dinoflagellate community and the potential of organic-walled dinoflagellates as eutrophication indicators in coastal waters (e.g., Dale and Fjellså, 1994; Dale et al., 1999; Dale, 2001, 2009; Pospelova et al., 2002, 2004; Matsuoka et al., 2003; Sangiorgi and Donders, 2004; Pospelova and Kim, 2010; Kim et al., 2012; Tian et al., 2018), although few areas were studied testing the effects of industrial pollution (e.g., Sætre et al., 1997; Dale, 2001; Pospelova et al., 2005; Liu et al., 2012; Aydin et al., 2015; Triki et al., 2017). Numerous studies showed that eutrophication signal can be identified by increased dinocyst concentrations in sediments along with nutrient input increases (Dale and Fjellså, 1994; Dale et al., 1999; Matsuoka, 1999; Persson et al., 2000; Pospelova et al., 2005; Rabalais et al., 2009; Liu et al., 2012; Zonneveld et al., 2012). However, Pospelova et al. (2002), in New Bedford Harbor and Apponagansett Bay (Massachusetts, USA), revealed that the observed increase in dinocyst taxa diversity from oligotrophic to mesotrophic conditions is followed by a decline in taxa richness when hypertrophic conditions occurred (i.e. extremely high nutrient levels); a "highly eutrophicated threshold" would then lead to an opposite effect on diversity. In addition, heterotrophic dinoflagellates positively react to increasing coastal water eutrophication, especially Protoperidinioids, Polykrikaceae, and diplopsalioideans (e.g., Thorsen and Dale, 1997; Matsuoka, 1999; Matsuoka et al., 2003; Kim et al., 2009; Krepakevich and Pospelova, 2010; Pospelova and Kim, 2010). It has been suggested that significant nutrient supplies from continental river runoff entailed the heterotrophic 
dinoflagellate population abundance by promoting diatom biomass production, thus enriching the prey stock (Matsuoka, 1999; Godhe and McQuoid, 2003; Kim et al., 2009). Dale (2001) also linked heterotrophic dinoflagellate increases to the reduced production of autotrophic dinoflagellates, in a context of decreasing light penetration.

Concerning specific taxa, Lingulodinium machaerophorum has often been shown to be sensitive to cultural eutrophication in estuarine environments and shows relative and absolute abundance increases along with the growing eutrophication in most studied environments (e.g., Dale and Fjellså, 1994; Dale et al., 1999; Sangiorgi and Donders, 2004; Dale, 2009; Harland et al., 2010; Shin et al., 2010; Zonneveld et al., 2012). However, regarding the whole dinoflagellate community, there is no consensus on a fossil dinocyst assemblage-type that would reflect nutrient enrichment in disturbed estuarine environments (Pospelova et al., 2002). Price et al. (2017b) concluded that there is no single species that characterizes eutrophic estuaries or high nutrient loading. Large fluctuations in cyst production are then frequently observed and amplified by the abrupt increase of one or two regionally specific taxa (for example Spiniferites spp.: in New Bedford Harbour, NE USA, Pospelova et al., 2002, as well as in the Bay of Brest, NW France, Lambert et al., 2018). Pospelova et al. (2002) stated that taxa considered as eutrophication markers in the Norwegian fjords show very different responses in shallow coastal US estuaries, also highlighting that $L$. machaerophorum does not respond positively to human eutrophication acceleration in US estuaries contrary to deep Norwegian fjords where stronger impacts on water mass stratification are observed. Recent studies indeed show that an increase of cultural eutrophication can have negative influences on L. machaerophorum abundances (Lambert et al., 2018 in NW France, Figure 8; Garcia-Moreiras et al., 2018 in NW Spain). Differences in geomorphology, hydrology, temperature and salinity between eutrophic estuaries thus result in different taxa responses to eutrophication (Price et al., 2017b). At the same time, some 
authors have shown that higher water temperatures could increase the vertical stability and influence the growth rates and the metabolism of the autotrophic dinoflagellates, contributing to increasing cyst production at the end of blooms (Godhe and McQuoid, 2003; Elshanawany et al., 2010) and highlighting the combined action of natural climatic variability and humaninduced eutrophication on recent dinocyst concentration increases.

Furthermore, Dale $(2001,2009)$ pointed out that dinocysts show different responses to nutrient enrichment and industrial pollution. Indeed, several authors also noticed that if nutrient enrichment significantly increases the dinocyst abundances, industrial pollution decreases their abundances or changes the heterotrophic/autotrophic ratio (Sætre et al., 1997; Liu et al., 2012). Liu et al. (2012) showed that autotrophic cysts react more sensitively to industrial pollution than heterotrophic ones, even if the physiological mechanisms behind this difference remain unclear. Some authors then hypothesize that toxic compounds could affect the vegetative cell physiology, inducing a decrease of cell proliferation and an enhancement of cyst production rates so as to survive in unfavorable environmental conditions, with more difficulties to germinate under high metal concentrations in the water column (Lage et al., 1994; Okamoto and Colepicolo, 1998; Godhe and McQuoid, 2003; Leitão et al., 2003; Liu et al., 2012; Herzi et al., 2013, Aydin et al., 2015; Triki et al., 2017). 


\section{Perspective works: the potential of the ancient DNA for the reconstructions of dinoflagellate dynamics}

In parallel with micropaleontological studies, innovative studies targeting the ancient DNA quantification are increasingly used in paleoecological and paleoenvironmental studies. The idea that the DNA retrieved in ancient sedimentary archives (ancient DNA) can be preserved for long periods of time has long been considered impossible because of the fragility of the DNA molecule and its rapid degradation by microorganisms. Indeed, when in its hydrated form, the DNA is subject to numerous abiotic (hydration, oxidation, UV damage) and biotic (microbial nuclease) degradation processes that lead to its fragmentation (Willerslev and Cooper 2005). Despite its potential degradation, DNA has been shown to be well preserved in cold, dry environments such as permafrost and glaciers (Willerslev et al., 2004, Orlando et al., 2013) and under anoxic conditions (Boere et al., 2011). Other physical factors such as low temperature, high pressure and high salinity also contribute to the preservation of DNA in sediments (Boere, 2010). DNA retrieved in marine sediment archives can be of different types and origins. After cell death or release into water, DNA molecules can undergo different transformations along the water column and in sediments, and eventually be degraded through biotic and abiotic processes and / or finally be preserved over the long term (Torti el al., 2015). Part of this DNA is deposited in marine and lacustrine sediments, either intracellularly (inside cells or dormant forms) or extracellularly (free outside cells). The resting forms of dormant organisms (cysts, spores, plant seeds, pollen) in sediments are thought to better preserve their DNA compared to organisms that do not have such resting stages. However, extracellular DNA has been shown to make up the bulk of total DNA in sediments and is generally associated with dead cells, organic and inorganic aggregates, and mineral matrices (Boere, 2010). In addition, it can protect against degradation by adsorbing to mineral matrices and refractory organic molecules (Pietramellara et al., 2009). It is estimated that between 50- 
95\% of the extracellular DNA could be protected against degradation (Danovaro et al., 2006, Dell'Anno et al., 2002). In addition, a part of the DNA corresponds to living organisms in the sediments.

Under ideal conditions of preservation (permafrost and ice), the theoretical limit for conserving old DNA is estimated at around one million years (Allentoft et al., 2012). However, the longest duration observed in these environments was 400,000 to 800,000 years (Willerslev et al., 2007). Recently, studies have shown that ancient DNA can be very well stored under oxic conditions (Lejzerowicz et al., 2013, Coolen et al., 2013, Capo et al., 2016). This demonstrates the potential of DNA as a paleoecological tool even in a variety of ecosystems and biological research domains. Ancient DNA has been studied since Poinar et al. (1998) isolated for the first time 20,000-year-old (plant and animal) DNA traces from coprolites (fossilized excreta). Since then, there has been a drastic increase in studies that have integrated ancient DNA analysis into paleoecological studies. Indeed, ancient DNA has been used to answer a variety of questions, such as paleoenvironments (de Bruyn et al., 2011; Willerslev et al., 2014), species biogeography and evolution (Mitchell et al., 2014), population dynamics and extinction processes (Shapiro et al., 2004; Drummond et al., 2005), or human evolution, diseases and dietary shifts (Green et al., 2010; Meyer et al., 2012; Adler et al., 2013; Krüttli et al., 2014; Metcalf et al., 2014). Ancient DNA has been used to reconstruct past environments and assess ecosystem changes over time but also to reconstruct changes in biological communities such as viruses dating back to 7,000 years in the Black Sea (Coolen, 2011), bacteria dating back to 217,000 years in the Mediterranean (Coolen and Overmann , 2007), mushrooms of at least 16,000 years (Lyodolph et al., 2005, Bellemain et al., 2013), plants of at least 10,000 years old (Parducci et al., 2013, Pedersen et al., 2013), and animals (mammoths and horses) of at least 7,000 years old (Haile et al., 2009). Regarding planktonic organisms, several studies showed that ancient DNA can be conserved across the 
Pleistocene timescale in various environments, from lakes to marine ecosystems. Indeed, the analysis of sediment cores taken at 5,000m water depth in the Atlantic Ocean off Brazil (Lejzerowicz et al., 2013) and at $900 \mathrm{~m}$ in the Black Sea (Coolen et al., 2013) allowed recovering ancient DNA sequences of dinoflagellates, coccoliths, foraminifera and copepods up to 32,500 years old. Ancient DNA has been used to study dinoflagellate and haptophyte successions in the Arctic, Antarctic, Black Sea and Mediterranean sediments (Boere et al., 2011, Coolen et al., 2006; D'Andrea et al., 2006), allowing to reconstruct ancient planktonic community dynamics and their responses to environmental changes (e.g., Boere et al., 2011; Domaizon et al., 2013; Lejzerowicz et al., 2013; Coolen et al., 2013; Pawlowska et al., 2014; Capo et al. 2016; Li et al., 2016).

In the northwestern part of France, and more specifically in a highly anthropized estuary (Bay of Brest, Brittany), ancient DNA has been collected to reconstruct the invasive pattern of the potentially toxic dinoflagellate Alexandrium minutum over a time scale of almost 150 years (Klouch et al., 2016). The presence of A. minutum was indeed detected by quantitative PCR (qPCR) using specific primers (ITS rDNA) with an upsurge since the 1980s (Klouch et al., 2016; Figure 8). A. minutum is one of the major toxin producers leading to the toxification of shellfish resources making their consumption dangerous. It is a widely distributed, coastal species that has been associated with paralytic toxins like saxitoxins (Taylor et al., 1995; Landsberg, 2002; Aylagas et al., 2014). Thanks to a multi-proxy approach combining paleogenetic and palynological (dinocysts and pollen grains) carried out at a very high (annual) resolution (Lambert et al., 2018), increasing abundances of A. minutum since the 1980s has been associated to a warming climate trend superimposed on changes in Bay of Brest agriculture practices in watersheds (Figure 8). Changes in the structure of the dinocyst community observed in the Bay of Brest (i.e. major trophic relay between $L$. machaerophorum and S. bentorii around 1965 followed then by S. membranaceus around 
1985 observed by palynological analyses), and the intensification of toxic algal blooms (i.e. A. minutum, detected by genetic analyses), both appear directly correlated to increasing atmospheric temperatures as well as increasing fertilizers (nitrates) for agriculture over the past decades in Bay of Brest watersheds (Figure 8). 


\section{Conclusion}

About $15 \%$ of dinoflagellates (aquatic protists) are known to produce resting cysts (dinoflagellate cysts or dinocysts) with morphology generally species-specific allowing to reconstruct paleoenvironments at different timescale over several (tens to hundreds of) millions of years (from the Middle Triassic, $240 \mathrm{Ma}$ ), (tens to hundreds of) thousands of years, to the pluridecadal timescales of human temporal perception.

Regarding the growing concerns about current climate change, dinocysts constitute a valuable tool to better understand ocean and climate variability, shed light on ecosystem responses to rapid climate changes and/or environmental perturbations, and to provide quantitative data needed to further constrain and validate models that are used for near-future climate simulations.

Furthermore, palynological studies conducted in parallel with paleogenetic studies could help to disentangle driving mechanisms responsible for recent changes in the structure of phytoplankton communities affecting coastal ecosystems, and especially causes responsible for the strong development of toxin-producing species under increasing influence of anthropogenic activities on watersheds.

\section{Acknowledgements}

This paper is a true equal participation of all co-authors that contributed to the same percentage of the final manuscript. Each co-author thanks their research institutes. We are very grateful for the constructive comments from Stijn De Schepper that greatly improved this manuscript. 


\section{References}

Adler, C. J., Dobney, K., Weyrich, L. S., Kaidonis, J., Walker, A. W., Haak, W., Bradshaw C.J., Townsend, G., Sołtysiak, A., Alt, K.W., Parkhill, J., Cooper, A., 2013. Sequencing ancient calcified dental plaque shows changes in oral microbiota with dietary shifts of the Neolithic and Industrial revolutions. Nature Genetics 45, 450-455.

Allentoft, M. E., Collins, M., Harker, D., Haile, J., Oskam, C. L., Hale, M. L., Campos, P.F., Samaniego, J.A., Gilbert, M.T., Willerslev, E., Zhang, G., Scofield, R.P., Holdaway, R.N., Bunce, M., 2012. The half-life of DNA in bone: measuring decay kinetics in 158 dated fossils. Proceedings of the Royal Society B 279, 4724-4733.

Anderson, D.M., Burkholder, J.M., Cochlan, W.P., Glibert, P.M., Gobler, C.J., Heil, C.A., Kudela, R.M., Parsons, M.L., Rensel, J.E.J., Townsend, D.W., Trainer, V. L., Vargo, G.A., 2008. Harmful algal blooms and eutrophication: examining linkages from selected coastal regions of the United States. Harmful Algae 8, 39-53.

Auffret, G., Zaragosi, S., Dennielou, B., Cortijo, E., Van Rooij, D., Grousset, F., Pujol, C., Eynaud, F., Siegert, M., 2002. Terrigenous fluxes at the Celtic margin during the last glacial cycle. Marine Geology 188, 79-108.

Aydin, H., Yürür, E.E., Uzar, S., Küçüksezgin, F., 2015. Impact of industrial pollution on recent dinoflagellate cysts in Izmir Bay (Eastern Aegean). Marine pollution bulletin 94, 144152.

Aylagas, E., Menchaca, I., Laza-Martínez, A., Seoane, S., Franco, J., 2014. Evaluation of marine phytoplankton toxicity by application of marine invertebrate bioassays. Scientia Marina 78, 173-183.

Barker, S., 2016. Dissolution of Deep-Sea Carbonates, In: Elias, Scott A. ed. Reference Module in Earth Systems and Environmental Sciences, Elsevier. https://doi.org/10.1016/B978-0-12-409548-9.09717-7

Barker, S., Cacho, I., Benway, H., Tachikawa, K., 2005. Planktonic foraminiferal $\mathrm{Mg} / \mathrm{Ca}$ as a proxy for past oceanic temperatures: a methodological overview and data compilation for the Last Glacial Maximum. Quaternary Science Reviews 24, 821-834.

Bellemain, E., Davey, M. L., Kauserud, H., Epp, L. S., Boessenkool, S., Coissac, E., Geml, J., Edwards, M., Willerslev, E., Gussarova, G., Taberlet, P., Haile, J., Brochmann, C., 2013. Fungal palaeodiversity revealed using high-throughput metabarcoding of ancient DNA from arctic permafrost. Environmental Microbiology 15, 1176-1189.

Bijl, P.K., Houben, A.J.P., Bruls, A., Pross, J., Sangiorgi, F., 2018. Stratigraphic calibration of Oligocene-Miocene organic-walled dinoflagellate cysts from offshore Wilkes Land, East Antarctica, and a zonation proposal. Journal of micropaleontology 37, 105-138.

Boere, A., 2010. Validation and application of fossil DNA as a recorder of past marine ecosystems and environmental conditions. PhD thesis, Netherlands. 175pp. 
Boere, A. C., Sinninghe Damsté, J. S., Rijpstra, W. I. C., Volkman, J. K., Coolen, M. J. L., 2011. Source-specific variability in post-depositional DNA preservation with potential implications for DNA based paleoecological records. Organic Geochemistry 42, 1216-1225.

Bogus, K. Mertens, K.N., Lauwaert, J., Harding, I.C., Vrielinck, H., Zonneveld, K.A.F., Versteegh, G.J.M., 2014. Differences in the chemical composition of organic-walled dinoflagellate resting cysts from phototrophic and heterotrophic dinoflagellates. Journal of Phycology 50, 254-266.

Bolch, C.J., Blackburn, S.I., Cannon, J.A., Hallegraeff, G.M., 1991. The resting cyst of the red tide dinoflagellate Alexandrium minutum Halim (Dinophyceae). Phycologia 30, 215-219.

Bond, G. C., Lotti, R., 1995. Iceberg discharges into the North Atlantic on millennial time scales during the last glaciation. Science 267, 1005-1010.

Bouimetarhan, I., Marret, F., Dupont, L., Zonneveld, K., 2009. Dinoflagellate cyst distribution in marine surface sediments off West Africa $\left(17-6^{\circ} \mathrm{N}\right)$ in relation to sea-surface conditions, freshwater input and seasonal coastal upwelling. Marine Micropaleontology 71, 113-130.

Bravo I., Figueroa R.I., 2014. Towards an Ecological Understanding of Dinoflagellate Cyst Functions. Microorganisms 2, 11-32.

Bricker, S.B., Longstaff, B., Dennison, W., Jones, A., Boicourt, K., Wicks, C., Woerner, J., 2008. Effects of nutrient enrichment in the nation's estuaries: a decade of change. Harmful Algae 8, 21-32.

Bujak, J.P., Davies, E.H., 1983. Modern and fossil Peridiniineae. American Association of Stratigraphic Palynologists Contribution Series 13, 216 pp.

Bujak, J.P., Williams, G.L., 1981. The evolution of dinoflagellates. Canadian Journal of Botany 59, 2077-2087.

Butterfield, N.J., Rainbird, R.H., 1998. Diverse organic-walled fossils, including "possible dinoflagellates," from the early Neoproterozoic of arctic Canada. Geology 26, 963-966.

Cacho, I., Grimalt, J. O., Canals, M., Sbaffi, L., Shackleton, N. J., Schönfeld, J., Zahn, R., 2001. Variability of the western Mediterranean Sea surface temperature during the last 25,000 years and its connection with the Northern Hemisphere climatic changes. Paleoceanography, $16,40-52$.

Calado, A.J., Moestrup, Ø., 2005. On the freshwater dinoflagellates presently included in the genus Amphidinium, with a description of Prosoaulax gen. nov. Phycologia 44, 112-119.

Calandra, F., 1964. Sur un présumé dinoflagellé Arpylorus nov. gen., du Gothlandien de Tunisie. Comptes Rendus de l'Académie des Sciences, Paris, 258, 4112-4114.

Capo E., Debroas, D., Arnaud, F., Guillemot, T., Bichet, V., Millet, L., Gauthier, E., Massa, C., Develle, A.-L., Pignol, C., Lejzerowicz, F., Domaizon, I., 2016. Long-term dynamics in 
microbial eukaryotes communities: a palaeolimnological view based on sedimentary DNA. Molecular Ecology 25, 5925-5943.

Carpenter, S.R., Caraco, N.F., Correll, D.L., Howarth, R.W., Sharpley, A.N., Smith, V.H., 1998. Nonpoint pollution of surface waters with phosphorus and nitrogen. Ecological applications 8, 559-568.

Caulle, C., Penaud, A., Eynaud, F., Zaragosi, S., Roche, D. M., Michel, E., Boulay, S., Richter, T., 2013. Sea-surface hydrographical conditions off South Faeroes and within the North-Eastern North Atlantic through MIS 2: The response of dinocysts. Journal of Quaternary Science 28, 217-228.

Chapman, D.V., Dodge, J.D., Heaney, S.I., 1982. Cyst formation in the dinoflagellate Ceratium hirundinella (Dinophyceae). Journal of Phycology 18, 121-129.

Charrieau, L.M., Filipsson, H.L., Nagai, Y., Kawada, S., Ljung, K., Kritzberg, E., Toyofuku, T., 2018. Decalcification and survival of benthic foraminifera under the combined impacts of varying $\mathrm{pH}$ and salinity. Marine Environmental Research.

https://doi.org/10.1016/j.marenvres.2018.03.015

Cookson, I. C., Eisenack, A., 1958. Microplankton from Australian and New Guinea Upper Mesozoic sediments. Proc. Royal Soc. Victoria 70, 19-79.

Cookson, I.C., Eisenack, A., 1960. Upper Mesozoic microplankton from Australia and New Guinea. Palaeontology 2, 243-61.

Coolen, M.J.L., 2011. 7000 Years of Emiliania huxleyi Viruses in the Black Sea. Science 333, $451-452$.

Coolen, M.J.L., Overmann, J., 2007. 217 000-year-old DNA sequences of green sulphur bacteria in Mediterranean sapropels and their implications for the reconstruction of the paleoenvironment. Environmental Microbiology 9, 238-249.

Coolen, M. J. L., Boere, A., Abbas, B., Baas, M., Wakenham, S. G., Sinninghe Damsté, J.S., 2006. Ancient DNA derived from alkenone-biosynthesizing haptophytes and other algae in Holocene sediments from the Black Sea. Paleoceanography 21, 1-17.

Coolen, M. J. L., Orsi, W. D., Balkema, C., Quince, C., Harris, K., Sylva, S. P., FilipovaMarinova, M., Giosan, L., 2013. Evolution of the plankton paleome in the Black Sea from the Deglacial to Anthropocene. PNAS 110. doi:10.1073/pnas.1219283110.

Crouch, E.M., Mildenhall, D.C., Neil, H.L., 2010. Distribution of organic-walled marine and terrestrial palynomorphs in surface sediments, offshore eastern New Zealand. Marine Geology 270, 235-256.

D’Andrea, W. J., Lage, M., Martiny, J. B. H., Laatsch, A. D., Amaral-Zettler, L.A., Sogin, M. L., Huang, Y., 2006. Alkenone producers inferred from well-preserved 18S rDNA in Greenland lake sediments. Journal of Geophysical Research 111, G03013. 
Dale, B., 2001. Marine dinoflagellate cysts as indicators of eutrophication and industrial pollution: a discussion. Science of the total environment 264, 235-240.

Dale, B., 2009. Eutrophication signals in the sedimentary record of dinoflagellate cysts in coastal waters. Journal of Sea Research 61, 103-113.

Dale, B., Fjellså, A., 1994. Dinoflagellate cysts as paleoproductivity indicators: state of the art, potential, and limits. In: Carbon cycling in the glacial ocean: Constraints on the ocean's role in global change. Springer, Berlin, Heidelberg, 521-537.

Dale, B., Thorsen, T. A., Fjellså, A., 1999. Dinoflagellate cysts as indicators of cultural eutrophication in the Oslo fjord, Norway. Estuarine Coastal and Shelf Science 48, 371-382.

Danovaro, R. Corinaldesi, C. Luna, G. Dell'Anno, A., 2006. Molecular tools for the analysis of DNA in marine environments. In: Marine Organic Matter: Biomarkers, Isotopes and DNA. Springer, Berlin, 105-126.

Dansgaard, W., Johnsen, S. J., Clausen, H. B., Dahl-Jensen, D., Gundestrup, N. S., Hammer, C. U., Hvidberg, C. S., Steffensen, J. P., Sveinbjörnsdottir, A. E., Jouzel, J., Bond, G., 1993. Evidence for general instability of past climate from a 250-kyr ice-core record. Nature 364, 218-220.

Daugbjerg, N., Hansen, G., Larsen, J., Moestrup, Ø., 2000. Phylogeny of some of the major genera of dinoflagellates based on ultrastructure and partial LSU rDNA sequence data, including the erection of three new genera of unarmoured dinoflagellates. Phycologia 39, 302-317.

Davey, R.J., Verdier, J.P., 1973. An investigation of microplankton assemblages from latest Albian (Vraconian) sediments. Revista Espanola de Micropaleontologia 5, 173-212.

Deane, H., 1845. On the existence of Fossil Xanthidia in the chalk. Ann. Mag. Nat. Hist. 1 (16), 64-64.

de Bruyn, M., Hoelzel, A. R., Carvalho, G. R., Hofreiter, M., 2011. Faunal histories from Holocene ancient DNA. Trends in Ecology and Evolution 26, 405-413.

Deflandre, G., 1936. Microfossiles des silex crétacés Première Partie : Généralités. Flagellés. Annales Paléontologies 25, 151-191.

Deflandre, G., 1937. Microfossiles des silex crétacés Deuxième Partie : Généralités. Flagellés. Annales Paléontologie 26, 51-103.

Deflandre, G., 1938. Microplancton des mers jurassiques conservé dans les marnes de Villerssur-Mer (Calvados). Etude liminaire et considérations générales. Trv. Station Zool. Wimereux 13, 147-200.

Deflandre, G., Cookson, I.C. 1955. Fossil microplankton from Australian Late Mesozoic and Tertiary sediments. Australian Journal of Marine and Freshwater Research 6, 242-313. 
de Graciansky, P.C., Hardenbol, J., Jacquin, T., Vail, P.R., 1999. Mesozoic and Cenozoic Sequence Stratigraphy of European Basins. SEPM Society for Sedimentary Geology 60, 763781.

Dell'Anno, A., Bompadre, S., Danovaro, R., 2002. Quantification, base composition, and fate of extracellular DNA in marine sediments. Limnological Oceanography 47, 899-905.

De Schepper, S., Schreck, M., Beck K.M., Matthiessen, J., Fahl, K., Mangerud G., 2015. Early Pliocene onset of modern Nordic Seas circulation related to ocean gateway changes. Nature Communications 6, DOI: 10.1038/ncomms9659.

de Vernal, A., Rochon, A., Hillaire-Marcel, C., Turon, J.-L., Guiot, J., 1993. Quantitative Reconstruction of Sea-Surface Conditions, Seasonal Extent of Sea-Ice Cover and Meltwater Discharges in High Latitude Marine Environments from Dinoflagellate Cyst Assemblages, in: Peltier, W.R. (Ed.), Ice in the Climate System, NATO ASI Series. Springer, Berlin, Heidelberg, 611-621.

de Vernal, A., Henry, M., Bilodeau, G., 1999. Technique de préparation et d'analyse en micropaléontologie. Les Cahiers du GEOTOP vol. 3, Université du Québec à Montréal, Montréal, Canada.

de Vernal, A., Hillaire-Marcel, C., 2000. Sea-ice cover, sea-surface salinity and halo/thermocline structure of the northwest North Atlantic: Modern versus full glacial conditions. Quaternary Science Reviews 19, 65-85.

de Vernal, A., Henry, M., Matthiessen, J., Mudie, P.J., Rochon, A., Boessenkool, K.P., Eynaud, F., GrØsfjeld, K., Guiot, J., Hamel, D., Harland, R., Head, M.J., Kunz-Pirrung, M., Levac, E., Loucheur, V., Peyron, O., Pospelova, V., Radi, T., Turon, J.-L., Voronina, E., 2001. Dinoflagellate cyst assemblages as tracers of sea-surface conditions in the northern North Atlantic, Arctic and sub-Arctic seas: the new ' $n=677$ ' data base and its application for quantitative palaeoceanographic reconstruction. Journal of Quaternary Science 16, 681-698.

de Vernal, A., Eynaud, F., Henry, M., Hillaire-Marcel, C., Londeix, L., Mangin, S., Matthiessen, J., Marret, F., Radi, T., Rochon, A., Solignac, S., Turon, J.-L., 2005. Reconstruction of sea-surface conditions at middle to high latitudes of the Northern Hemisphere during the Last Glacial Maximum (LGM) based on dinoflagellate cyst assemblages. Quaternary Science Reviews 24, 897-924.

de Vernal, A., Rosell-Melé, A., Kucera, M., Hillaire-Marcel, C., Eynaud, F., Weinelt, M., Dokken, T., Kageyama, M., 2006. Comparing proxies for the reconstruction of LGM seasurface conditions in the northern North Atlantic. Quaternary Science Reviews 25, 2820 2834.

de Vernal, A., Rochon, A., Fréchette, B., Henry, M., Radi, T., Solignac, S., 2013a. Reconstructing past sea ice cover of the Northern Hemisphere from dinocyst assemblages: Status of the approach. Quaternary Science Reviews 79, 122-134.

de Vernal, A., Gersonde, R., Goosse, H., Seidenkrantz, M.-S., Wolff, E. W., 2013b. Sea ice in the paleoclimate system: the challenge of reconstructing sea ice from proxies - an introduction. Quaternary Science Reviews 79, 1-8. 
Diaz, R.J., Rosenberg, R., 2008. Spreading dead zones and consequences for marine ecosystems. Science 321, 926-929.

Dodge, J.D., Harland, R.,1991. The distribution of planktonic dinoflagellates and their cysts in the eastern and northeastern Atlantic Ocean. New Phytologist 118, 593-603.

Dokken, T. M., Jansen., E., 1999. Rapid Changes in the Mechanism of Ocean Convection during the Last Glacial Period. Nature 401, 458-61.

Dokken, T. M., Nisancioglu, K. H., Li, C., Battisti, D. S., and Kissel, C., 2013. DansgaardOeschger Cycles: Interactions between Ocean and Sea Ice Intrinsic to the Nordic Seas. Paleoceanography 28, 491-502.

Domaizon, I., Savichtcheva, O., Debroas, D., Arnaud, F., Villar, C., Pignol, C., Alric, B., Perga, M.E., 2013. DNA from lake sediments reveals the long-term dynamics and diversity of Synechococcus assemblages. Biogeosciences 10, 3817-3838.

Donders, T.H., van Helmond, N.A.G.M, Verreussel, R., Munsterman, D., ten Veen, J., Speijer, R.P., Weijers, J.W.H., Sangiorgi, F., Peterse, F., Reichart, G.-J., Sinninghe Damsté, J.S., Lourens, L., Kuhlmann, G., Brinkhuis, H., 2018. Land-sea coupling of early Pleistocene glacial cycles in the southern North Sea exhibit dominant Northern Hemisphere forcing. Climate of the Past 14, 397-411.

Dörhöfer, G., Davies, E.H., 1980. Evolution of archeopyle and tabulation in rhaetogonyaulacinean dinoflagellate cysts. Miscellaneous Publication, Royal Ontario Museum, Life Sciences Division, Toronto, Canada, 91 pp.

Drummond, A. J., Rambaut, A., Shapiro, B., Pybus, O.G., 2005. Bayesian coalescent inference of past population dynamics from molecular sequences. Molecular Biology and Evolution 22, 1185-1192.

Eaton, G.L., 1980. Nomenclature and homology in peridinialean dinoflagellate plate patterns. Palaeontology 23, 667-688.

Ehlers, J., Gibbard, P.L., 2007. The extent and chronology of Cenozoic Global Glaciation. Quaternary International 164-165, 6-20.

Ehrenberg, C.G., 1836. Mittheilungen über die in den Feuersteinen bei Delitzsch vorkommenden mikroskopischen Algen und Bryozoen als Begleiter der fossilen infusorien. Verh. Preuss. Akad. Wiss. Berlin, 114-115.

Eisenack, A., 1938. Die Phosphoritknollen der Bersteinformation als Uberlieferer tertiären Planktons. Schriften Physokon. Gesellschaft Königsberg 70, 181-188.

Eisenack, A., Klement, K.W., 1964. Katalog der fossilen Dinoflagellaten, Hystrichosphären und verwandten Mikrofossilien Loseblattwerk, Band 1, Dinoflagellates. E. Schweizerbart'sche Verlag, Stuttgart. 
Eisenack A., Kjellström, G., 1972. Katalog der fossilen Dinoflagellaten, Hystrichosphären und verwandten Mikrofossilien, Band 2, Dinoflagellates. E. Schweizerbart'sche Verlag, Stuttgart.

Ellegaard, M., Head, M.J., Versteegh, G.J.M., in press. Linking biological and geological data on dinoflagellates: species concepts, nomenclature, and assessing approaches using the genus Spiniferites as an example. Palynology42, doi: 10.1080/01916122.2018.1465732.

Elshanawany, R., Zonneveld, K., Ibrahim, M.I., Kholeif, S.E., 2010. Distribution patterns of recent organic-walled dinoflagellate cysts in relation to environmental parameters in the Mediterranean Sea. Palynology 34, 233-260.

Esper, O., Zonneveld, K.A.F., 2002. Distribution of organic-walled dinoflagellate cysts in surface sediments of the Southern Ocean (eastern Atlantic sector) between the Subtropical Front and the Weddell Gyre. Marine Micropaleontology 46, 177-208.

Evitt, W.R.A., 1961. Observation of fossil dinoflagellates. Micropaleontology 7, 385-420.

Evitt, W.R.A., 1963. Discussion and proposals concerning fossil dinoflagellates, hystrichospheres and acritarchs. Proceedings of the National Academy of Sciences 49, 158 164.

Evitt, W.R.A., 1985. Sporopollenin Dinoflagellate Cysts. Their Morphology and Interpretation. American Association of Stratigraphic Palynologists Foundation, Dallas, Texas, $333 \mathrm{pp}$.

Evitt, W.R.A., Davidson, S.E., 1964. Dinoflagellate studies I. Dinoflagellate cysts and thecae. Standford Univ. Publ. Geol. Sc. 16, 1-12.

Eynaud, F., Turon, J.L., Sánchez-Goñi, M.F., Gendreau, S., 2000. Dinoflagellate cyst evidence of "Heinrich-like events" off Portugal during the marine isotopic stage 5. Marine Micropaleontology 40, 9-21.

Eynaud, F., Turon, J. L., Matthiessen, J., Kissel, C., Peypouquet, J. P., De Vernal, A., Henry, M., 2002. Norwegian sea-surface palaeoenvironments of marine oxygen-isotope stage 3: The paradoxical response of dinoflagellate cysts. Journal of Quaternary Science 17, 349-359.

Eynaud, F., Zaragosi, S., Scourse, J. D., Mojtahid, M., Bourillet, J. F., Hall, I. R., Penaud, A., Locascio, M., Reijonen, A., 2007. Deglacial laminated facies on the NW European continental margin: The hydrographic significance of British-Irish Ice Sheet deglaciation and Fleuve Manche paleoriver discharges. Geochemistry, Geophysics, Geosystems 8, doi:10.1029/2006GC001496.

Eynaud, F., De Abreu, L., Voelker, A., Schönfeld, J., Salgueiro, E., Turon, J. L., Penaud, A., Toucanne, S., Naughton, F., Sánchez Goñi, M. F., Malaizé, B., Cacho, I., 2009. Position of the Polar Front along the western Iberian margin during key cold episodes of the last $45 \mathrm{ka}$. Geochemistry, Geophysics, Geosystems 10, Q07U05, doi:10.1029/2009GC002398. 
Eynaud, F., 2011. Planktonic foraminifera in the Arctic: potentials and issues regarding modern and quaternary populations. IODP Conference Series: Earth and Environmental Science 14, 012005. https://doi.org/10.1088/1755-1315/14/1/012005.

Eynaud, F., Malaizé, B., Zaragosi, S., De Vernal, A., Scourse, J., Pujol, C., Cortijo, E., Grousset, F. E., Penaud, A., Toucanne, S., Turon, J. L., Auffret, G., 2012. New constraints on European glacial freshwater releases to the North Atlantic Ocean. Geophysical Research Letters 39, doi:10.1029/2012GL052100.

Fauconnier, D., Masure, E., (coord), Begouen, V., Cornu P., Courtinat B., Foucher J.C., Hssaida T., Lachkar G., Londeix L., Michoux D., Monteil E., Ogg G., Pourtoy D., Rauscher R., Soncini M.J., 2002. Guide pratique pour la détermination de kystes de Dinoflagellés fossiles : Les genres à processus et à archéopyle apical, Ed. BRGM \& MNHN, 550 pp.

Fensome, R.A., Gocht, H., Stover, L.E., Williams, G.L., 1991. The Eisenack Catalog of Fossil Dinoflagellates. E. Schweizerbart'sche Verlagsbuchhandlung, Stuttgart, Germany. New Series $1,828 \mathrm{pp}$.

Fensome, R.A., Taylor, F.J.R., Norris, G., Sarjeant, W.A.S., Wharton, D.I., Williams, G.L., 1993. A classification of living and fossil dinoflagellates. American Museum National History. Micropaleontology special publication, 7, Sheridan Press, Hanover, 351 pp.

Fensome, R.A., MacRae, R.A., Moldowan, J.M., Taylor, F.J.R., Williams, G.L., 1996. The early Mesozoic radiation of dinoflagellates. Paleobiology 22, 329-338.

Fensome, R.A., Williams, G.L., 2004. The Lentin and Williams Index of fossil dinoflagellates 2004 Edition. American Association of Stratigraphic Palynologists, Contributions Series 42, $909 \mathrm{pp}$.

Fensome, R.A., MacRae, R.A., Williams, G.L., 2008. DINOFLAJ2, Version 1. American Association of Stratigraphic Palynologists, Data Series 1. http://dinoflaj.smu.ca/wiki/Main.

Fensome, R.A., Williams, G.L., MacRae, R.A., 2009. Late Cretaceous and Cenozoic fossil dinoflagellates and other palynomorphs from the Scotian Margin, offshore eastern Canada. Journal of Systematic Palaeontology 7, 1-79.

Foucher, J.-C., 1979. Distribution stratigraphique des kystes de dinoflagellés et des acritarches dans le Crétacé supérieur du Bassin de Paris et de l'Europe Septentrionale. Palaeontographica Abteilung B 169, 78-105.

Foucher, J.-C., 1985. Dinoflagellates. In : Robaszynski, F., Bless, M.J.M., Felder, P.J., Foucher, J.-C., Legoux, O., Manivit, H., Meessen, J.P.M.S., Van der Tuuk, L.A. (Eds.). The Campanian-Maastrichtian boundary in the chalky facies close to the type-Maastrichtian area. Bulletin des Centres de Recherches Exploration Production Elf-Aquitaine 9, 32-40.

Frieling, J., Huurdeman, E.P., Rem, C.C.M., Donders, T.H., Pross, J., Bohaty, S.M., Holdgate, G.R., Gallagher, S.J., McGowran, B., Bijl, P.K., 2018. Identification of the Paleocene-Eocene boundary in coastal strata in the Otway Basin, Victoria, Australia. Journal of Micropalaeontology 37, 317-339. 
Frieling, J., Sluijs, A., 2018. Towards quantitative environmental reconstructions from ancient non-analogue microfossil assemblages: Ecological preferences of Paleocene - Eocene dinoflagellates. Earth-Science Reviews 185, 956-973.

Fukuyo, Y., 1985. Morphology of Protogonyaulax tamarensis (Lebour) Taylor and Protogonyaulax catenella (Whedon and Kofoid) Taylor from Japanese coastal waters. Bulletin of Marine Science 37, 529-537.

García-Moreiras, I., Pospelova, V., García-Gil, S., Sobrino, C.M., 2018. Climatic and anthropogenic impacts on the Ría de Vigo (NW Iberia) over the last two centuries: A highresolution dinoflagellate cyst sedimentary record. Palaeogeography Palaeoclimatology Palaeoecology 504, 201-218.

Gibb, O. T., Hillaire-Marcel, C., de Vernal, A., 2014. Oceanographic regimes in the northwest Labrador Sea since Marine Isotope Stage 3 based on dinocyst and stable isotope proxy records. Quaternary Science Reviews 92, 269-279.

Glasgow, H.B., Burkholder, J.M., 2000. Water quality trends and management implications from a five-year study of a eutrophic estuary. Ecological Applications 10, 1024-1046.

Glibert, P.M., Seitzinger, S., Heil, C.A., Burkholder, J.M., Parrow, M.W., Codispoti, L.A., Kelly, V., 2005. The role of eutrophication in the global proliferation of harmful algal blooms. Oceanography 18, 198-209.

Godhe, A., McQuoid, M.R., 2003. Influence of benthic and pelagic environmental factors on the distribution of dinoflagellate cysts in surface sediments along the Swedish west coast. Aquatic Microbial Ecology 32, 185-201.

Gómez, F., Moreira, D., López-Garcia, P., 2010. Neoceratium gen. nov., a new genus for all marine species currently assigned to Ceratium (Dinophyceae). Protist 161, 35-54.

Gómez, F., 2012. A checklist and classification of living dinoflagellates (Dinoflagellata, Alveolata). CICIMAR Océanides 27, 65-140.

González, C., Dupont, L. M., Mertens, K., Wefer, G. 2008. Reconstructing marine productivity of the Cariaco Basin during marine isotope stages 3 and 4 using organic-walled dinoflagellate cysts. Paleoceanography 23, PA3215, doi:10.1029/2008PA001602.

Gottschling, M., Soehner, S., Zinssmeister, C., John, U., Plötner, J., Schweikert, M., Aligizaki, K., Elbrächter, M., 2012. Delimitation of the Thoracosphaeraceae (Dinophyceae), including the calcareous dinoflagellates, based on large amounts of ribosomal RNA sequence data. Protist 163, 15-24.

Gray, D.D., Zonneveld, K.A.F., Versteegh, G.J.M., 2017. Species-specific sensitivity of dinoflagellate cysts to aerobic degradation: A five-year natural exposure experiment. Review of Palaeobotany and Palynology 247, 175-187.

Green, R. E., Krause, J., Briggs, A. W., Maricic, T., Stenzel, U., Kircher, M., et al., 2010. A draft sequence of the Neandertal genome. Science 328, 710-722. 
Gruas-Cavagnetto, C., Chateauneuf, J-J., Sittler, C., Meyer, K-J., 1988. The regional distribution of dinoflagellates; correlation of the interregional zonation with the local zones and with the regional lithostratigraphy. France: The Paris Basin. Paleogene Dinoflagellates. In: Vinken, R. (Ed.), The Northwest European Tertiary Basin. Results of the International Geological Correlation Programme, Project 124. Geologisches lahrbuch, Reihe A, Heft 100, 332-338.

Gu, H., Luo, Z., Mertens, K.N., Price, A.M., Turner, R.E., Rabalais, N.N., 2015. Cyst-motile stage relationship, morphology, ultrastructure, and molecular phylogeny of the gymnodinioid dinoflagellate Barrufeta resplendens comb. nov., formerly known as Gyrodinium resplendens, isolated from the Gulf of Mexico. Journal of Phycology 51, 990-999.

Guiot, J., 1990. Methodology of the last climatic cycle reconstruction in France from pollen data. Palaeogeography Palaeoclimatology Palaeoecology 80, 49-69.

Guiot, J., de Vernal, A., 2007. Chapter Thirteen Transfer Functions: Methods for Quantitative Paleoceanography Based on Microfossils, In: Hillaire-Marcel, C., de Vernal, A. (Eds.), Developments in Marine Geology. Elsevier, 523-563.

Guiot, J., de Vernal, A., 2011. Is spatial autocorrelation introducing biases in the apparent accuracy of paleoclimatic reconstructions? Quaternary Science Reviews 30, 1965-1972.

Haile, J., Froese, D. G., Macphee, R. D. E., Roberts, R. G., Arnold, L. J., Reyes, A. V, Rasmussen, M., Nielsen, R., Brook, B.W., Robinson, S., Demuro, M., Gilbert, M.T.P., Munch, K., Austin, J.J., Cooper, A., Barnes, I., Möller, P., Willerslev, E., 2009. Ancient DNA reveals late survival of mammoth and horse in interior Alaska. Proceedings of the National Academy of Sciences of the United States of America 106, 22352-22357.

Hammer, Ø., Harper, D.A.T., Ryan, P.D., 2001. Past: Paleontological Statistics Software Package for Education and Data Analysis. Palaeontologia Electronica 4 (1), 9 pp. http://palaeo-electronica.org/2001_1/past/issue1_01.htm.

Hansen, G., Daugbjerg, N., Henriksen, P., 2007. Baldinia anauniensis gen. et sp. nov.: a 'new' dinoflagellate from Lake Tovel, N. Italy. Phycologia 46, 86-108.

Haq, B.U., Hardenbol, J. Vail, P.R., 1987. Chronology of fluctuating sea level since the Triassic. Science 235, 1156-1167.

Hardenbol, J., Berggren, W., 1978. A new Paleogene numerical time scale. In: Cohee, G. V., Glaessner, M.F., Hedberg, H.D. (Eds.). Contributions to the geological timescale. American Association of Petroleum Geologists, Studies in Geology 6, 213-234.

Hardy, W., Penaud, A., Marret, F., Bayon, G., Marsset, T., Droz, L., 2016. Dinocyst assemblage constraints on oceanographic and atmospheric processes in the eastern equatorial Atlantic over the last 44 kyr. Biogeosciences 13, 4823-4841. https://doi.org/10.5194/bg-134823-2016.

Hardy, W., Marret, F., Penaud, A., le Mézo, P., Droz, L., Marsset, T., Kageyama, M., 2018. Quantification of Last Glacial-Holocene net primary productivity and upwelling activity in 
the equatorial eastern Atlantic with a revised modern dinocyst database. Palaeogeography Palaeoclimatology Palaeoecology, 10.1016/j.palaeo.2018.06.025.

Harland, R., 1982. A review of Recent and Quaternary organic-walled dinoflagellate cysts of the genus Protoperidinium. Palaeontology 25, 369-397.

Harland, R., 1983. Distribution maps of recent dinoflagellate cysts in bottom sediments from the North Atlantic Ocean and adjacent seas. Palaeontology 26, 321-387.

Harland, R., Nordberg, K., Filipsson, H.L., 2010. A major change in the dinoflagellate cyst flora of Gullmar Fjord, Sweden, at around 1969/1970 and its possible explanation. Geological Society, London, Special Publications, 344, 75-82.

Head, M.J., 1996. Modern dinoflagellate cysts and their biological affinities. In "Palynology: principles and Applications. Chapter 30." (Jansonius, J., and McGregor, D.C., editors), AASP Foundation, 1 197-1 248.

Heinrich, H., 1988. Origin and consequences of cyclic ice rafting in the Northeast Atlantic Ocean during the past 130,000 years. Quaternary Research 29, 142-152.

Helby, R., Morgan, R., Partridge, A.D., 1987. A palynological zonation of the Australian Mesozoic. In: Jell, P.A. (Ed.). Studies in Australian Mesozoic Palynology. Memoir of the Association of Australasian Palaeontologists 4, 1-94.

Hennissen, J., Head, M., De Schepper, S., Groeneveld, J., 2016. Dinoflagellate cyst paleoecology during the Pliocene-Pleistocene climatic transition in the North Atlantic. Palaeogeography Palaeoclimatology Palaeoecology 470, DOI: 10.1016/j.palaeo.2016.12.023

Herzi, F., Jean, N., Zhao, H., Mounier, S., Mabrouk, H.H., Hlaili, A.S., 2013. Copper and cadmium effects on growth and extracellular exudation of the marine toxic dinoflagellate Alexandrium catenella: 3D-fluorescence spectroscopy approach. Chemosphere 93, 1230 1239.

Hillaire-Marcel, C., de Vernal, A., 2008. Stable isotope clue to episodic sea ice formation in the glacial North Atlantic. Earth and Planetary Science Letters 268, 143-150.

Holzwarth, U., Esper, O., Zonneveld, K., 2007. Distribution of organic-walled dinoflagellate cysts in shelf surface sediments of the Benguela upwelling system in relationship to environmental conditions. Marine Micropaleontology 64, 91-119.

Holzwarth, U., Meggers, H., Esper, O., Kuhlmann, H., Freudenthal, T., Hensen, C., Zonneveld, K.A.F., 2010. NW African climate variations during the last 47,000 years: Evidence from organic-walled dinoflagellate cysts. Palaeogeography Palaeoclimatology Palaeoecology 291, 443-455.

Hutson, W.H., 1980. The Agulhas Current during the Late Pleistocene: Analysis of Modern Faunal Analogues. Science 207, 64-66. 
Imbrie, J., Kipp, N.G., 1971. A new micropaleontological method for quantitative paleoclimatology: Application to a Late Pleistocene Caribbean core. The Late Cenozoic Glacial Ages, Yale Univ. Press, New Haven 71-181.

IPCC, 2014. In: Core Writing Team, Pachauri, R.K., Meyer, L.A. (Eds.), Climate Change 2014: Synthesis Report. Contribution of Working Groups I. II and III to the Fifth Assessment Report of the intergovernmental panel on Climate Change. IPCC, Geneva, Switzerland, 151 pp.

Jan du Chêne, R., Masure, E., Becheler, I., Biffi, U., De Vains, G., Fauconnier, D., Ferrario, R., Foucher, J.-C., Gaillard, M., Hochuli, P., Lachkar, G., Michoux, D. Monteil, E., Moron, J.-M., Rauscher, R., Raynaud, J.-F., Taugourdeau, J., Turon, J.-L. 1986. Guide pratique pour la détermination de kystes de Dinoflagellés fossiles : le complexe Gonyaulacysta. Bull. Centres Rech. Explor.-. Prod. Elf-Aquitaine Mem. 12, 479 pp.

Janouskovec, J., Gavelis, G.S., Burki, F., Dinh, D., Bachvaroff, T.R., Gornik, S.G., Bright, K. J., Imanian, B., Strom, S.L., Delwiche, C.F., Waller, R. F., Fensome, R. A., Leander, B. S., Rohwer, F. L., Saldarriaga, J.F., 2016. Major transitions in dinoflagellate evolution unveiled by phylotranscriptomics. PNAS 27, 171-180.

Javaux, E., Marshall, C., Bekker, A. 2010. Organic-walled microfossils in 3.2-billion-year-old shallow-marine siliciclastic deposits. Nature 463, 934-938.

Kim, S.Y., Moon, C.H., Cho, H.J., Lim, D.I., 2009. Dinoflagellate cysts in coastal sediments as indicators of eutrophication: a case of Gwangyang Bay, South Sea of Korea. Estuaries and Coasts 32, 1225-1233.

Kim, S.-Y., Scourse, J., Marret, F., Lim, D.-I., 2010. A 26,000-year integrated record of marine and terrestrial environmental change off Gabon, west equatorial Africa.

Palaeogeography Palaeoclimatology Palaeoecology 297, 428-438.

Kim, S.Y., Lim, D.I., Cho, H.J., 2012. Dinoflagellate cyst assemblages from the northern shelf sediments of the East China Sea: an indicator of marine productivity. Marine Micropaleontology 96, 75-83.

Kindler, P., Guillevic, M., Baumgartner, M., Schwander, J., Landais, A., Leuenberger, M., 2014. Temperature reconstruction from 10 to $120 \mathrm{kyr}$ b2k from the NGRIP ice core. Climate of the Past 10, 887-902.

Klouch, K.Z., Schmidt, S., Andrieux-Loyer, F., Le Gac, M., Hervio-Heath, D., Qui-Minet, Z.N., Quéré, J., Bigeard, E., Guillou, L., Siano, R., 2016. Historical records from dated sediment cores reveal the multidecadal dynamic of the toxic dinoflagellate Alexandrium minutum in the Bay of Brest (France). FEMS microbiology ecology 92, p. fiw101.

Kobayashi, S., Matsuoka, K., 1995. A new species of Ensiculifera, E. imariense (Dinophyceae), producing organic-walled cysts. Journal of Phycology 31, 147-152.

Krepakevich, A., Pospelova, V., 2010. Tracing the influence of sewage discharge on coastal bays of Southern Vancouver Island (BC, Canada) using sedimentary records of phytoplankton. Continental Shelf Research 30, 1924-1940. 
Krüttli, A., Bouwman, A., Akgül, G., Casa, P. Della, Rühli, F., Warinner, C., 2014. Ancient DNA analysis reveals high frequency of European lactase persistence allele (T-13910) in medieval Central Europe. PLoS ONE 9, doi:10.1371/journal.pone.0086251.

Kucera, M., 2007. Chapter Six Planktonic Foraminifera as Tracers of Past Oceanic Environments, in: Developments in Marine Geology. Elsevier, 213-262. https://doi.org/10.1016/S1572-5480(07)01011-1.

Lage, O.M., Parente, A.M., Soares, H.M.V.M., Vasconcelos, M.T.S.D., Salema, R., 1994. Some effects of copper on the dinoflagellates Amphidinium carterae and Prorocentrum micans in batch culture. European Journal of Phycology 29, 253-260.

Lambert, C., Penaud, A., Vidal, M., Klouch, K., Gregoire, G., Ehrhold, A., Eynaud, F., Schmidt, S., Ragueneau, O., Siano, R., 2018. Human-induced river runoff overlapping natural climate variability over the last 150 years: Palynological evidence (Bay of Brest, NW France). Global and Planetary Change 160, 109-122.

Landsberg, J.H., 2002. The effects of harmful algal blooms on aquatic organisms. Reviews in Fisheries Science 10, 113-390.

Le Hérissé, A., Masure, E., Javaux, E., Craig, J. 2012. The end of myth: Arpylorus antiquus Paleozoic dinoflagellate. Palaios 27, 414-423.

Leitão, M.D.S., Cardozo, K.H.M., Pinto, E., Colepicolo, P., 2003. PCB-induced oxidative stress in the unicellular marine dinoflagellate Lingulodinium polyedrum. Archives of environmental contamination and toxicology 45, 59-65.

Lejzerowicz, F., Esling, P., Majewski, W., Szczucin, W., Decelle, J., Obadia, C., Arbizu, P.M., Pawlowski, J., 2013. Ancient DNA complements microfossil record in deep-sea subsurface sediments. Biology Letters 9, doi:10.5061/dryad.b5m0j

Lentin, J.K., Williams, G. L., 1981. Fossil dinoflagellates: Index to genera and species, 1981 edition. Bedford Institute of Oceanography, Report Series, BI-R-81-12, 345 pp.

Lentin, J.K., Williams, G.L., 1993. Fossil dinoflagellates: Index to genera and species. 1993 edition. American Association of Stratigraphic Palynologists, Contributions Series 28, $856+$ viii pp.

Lentin, J.K., Williams, G.L., 1973. Fossil dinoflagellates: Index to genera and species. Geological Survey of Canada, Paper.73-42, 176 pp.

Leppig, U., Montenari, M., 2000. Organic-walled microfossils of possible dinoflagellate affinity from the Lower Permian of Sonora (northwest Mexico). Marine Micropalaeontology $40,1-8$.

Lewis, J., 1991. Cyst-theca relationships in Scrippsiella (Dinophyceae) and related orthoperidinioid genera. Botanica Marina 34, 91-106. 
Lewis, J., Rochon, A., Ellegaard, M., Mudie P.J., Harding, I., 2001. The cyst-theca relationship of Bitectatodinium tepikiense (Dinophyceae). European Journal of Phycology 36, 137-146.

Li, G., Dong, H., Hou, W, Wang, S., Jiang H., Yang, J., Wu, G., 2016. Temporal succession of ancient phytoplankton community in Qinghai lake and implication for paleo-environmental change. Scientific Reports 6, 19769.

Limoges, A., Londeix, L., de Vernal, A., 2013. Organic-walled dinoflagellate cyst distribution in the Gulf of Mexico. Marine Micropaleontology 102, 51-68.

Limoges, A., Mertens, K.N., de Vernal, A., Ruíz-Fernández, A.-C., 2015. First report of subrecent fossilized cysts produced by the benthic dinoflagellate Bysmatrum subsalsum (Dinophyceae) from a shallow Mexican lagoon in the Gulf of Mexico. Journal of Phycology 51, 211-215.

Lister, T.R., 1970. The acritarchs and chitinozoa from the Wenlock and Ludlow Series of the Ludlow and Millichope areas, Shropshire. Part 1. Palaeontographical Society Monographs $124,100 \mathrm{pp}$.

Litaker, R.W., Vandersea, M.W., Kibler, S. R., Madden, V. J., Noga, E. J., Tester, P.A., 2002. Life cycle of the heterotrophic dinoflagellate Pfiesteria piscicida. Journal of Phycology 38, $442-463$.

Liu, D., Shi, Y., Di, B., Sun, Q., Wang, Y., Dong, Z., Shao, H., 2012. The impact of different pollution sources on modern dinoflagellate cysts in Sishili Bay, Yellow Sea, China. Marine Micropaleontology 84, 1-13.

Liu, T., Mertens, K.N., Ribeiro, S., Ellegaard, M., Matsuoka, H., Gu, H., 2015a. Cyst-theca relationships and phylogenetic positions of Peridiniales (Dinophyceae) with two anterior intercalary plates, with description of Archaeperidinium bailongense sp. nov. and Protoperidinium fuzhouense sp. nov. Phycological Research 63, 134-151.

Liu, T., Mertens, K.N. Gu, H., 2015b. Cyst-theca relationship and phylogenetic positions of the diplopsaloideans (Peridiniales, Dinophyceae), with description of Niea and Qia gen. nov. Phycologia 54, 210-232.

Lydolph, M. C., Jacobsen, J., Arctander, P., Gilbert, M. T. P., Gilichinsky, D. A., Hansen, A. J., Willerslev, E., Lange, L., 2005. Beringian paleoecology inferred from permafrostpreserved fungal DNA. Applied and Environmental Microbiology 71, 1012-1017.

MacRae, A., Fensome, R.A., Williams, G.L., 1996. Fossil dinoflagellate diversity, originations, and extinctions and their significance. Canadian Journal of Botany 74, 16871694.

Manno, C., Pavlov, A.K., 2014. Living planktonic foraminifera in the Fram Strait (Arctic): absence of diel vertical migration during the midnight sun. Hydrobiologia 721, 285-295.

Marret, F., 1994. Distribution of dinoflagellate cysts in recent marine sediments from the east Equatorial Atlantic (Gulf of Guinea). Review of Palaeobotany and Palynology 84, 1-22. 
Marret, F., Turon, J.L., 1994. Paleohydrology and paleoclimatology off Northwest Africa during the last glacial-interglacial transition and the Holocene: Palynological evidences. Marine Geology 118, 107-117.

Marret, F., de Vernal, A., 1997. Dinoflagellate cyst distribution in surface sediments of the southern Indian Ocean. Marine Micropaleontology 29, 367-392.

Marret, F., de Vernal, A., Benderra, F., Harland, R., 2001. Late Quaternary sea-surface conditions at DSDP Hole 594 in the southwest Pacific Ocean based on dinoflagellate cyst assemblages. Journal of Quaternary Science 16, 739-751.

Marret, F., Zonneveld, K.A.F., 2003. Atlas of modern organic-walled dinoflagellate cyst distribution. Review of Palaeobotany and Palynology 125, 1-200.

Marret, F., Scourse, J., Kennedy, H., Ufkes, E., Jansen, J.H.F., 2008. Marine production in the Congo-influenced SE Atlantic over the past 30,000 years: A novel dinoflagellate-cyst based transfer function approach. Marine Micropaleontology 68, 198-222.

Matsuoka, K., 1988. Cyst-theca relationships in the diplopsalid group (Peridiniales, Dinophyceae). Review of Palaeobotany and Palynology 56, 95-122.

Matsuoka, K., 1999. Eutrophication process recorded in dinoflagellate cyst assemblages-a case of Yokohama Port, Tokyo Bay, Japan. Science of the Total Environment 231, 17-35.

Matsuoka, K., Joyce, L.B., Kotani, Y., Matsuyama, Y., 2003. Modern dinoflagellate cysts in hypertrophic coastal waters of Tokyo Bay, Japan. Journal of Plankton Research 25, 14611470.

Matsuoka, K., Kawami, H., 2013. Phylogenetic subdivision of the genus Protoperidinium, (Peridiniales, Dinophyceae) with emphasis on the Monovela Group. In: Biological and geological perspectives of dinoflagellates (Ed. by J. M. Lewis, F. Marret and L. Bradley), 267-276. The Micropalaeontological Society, Special Publications. Geological Society, London.

McNeill, J., Barrie, F.R., Buck, W.R., Demoulin, V., Greuter, W., Hawksworth, D.L., Herendeen, P.S., Knapp, S., Prado, J., Prud'homme van Reine, W.F., Smith, G.F., Wiersema, J.H., Turland, N.J., 2012. International Code of Nomenclature for algae, fungi and plants (Melbourne Code) adopted by the Eighteenth International Botanical Congress Melbourne, Australia, July 2011. Regnum Vegetabile 154, 1-208. Königstein: Koeltz Scientific Books.

Mertens, K.N., Takano, Y., Head, M.J., Matsuoka, K., 2014. Living fossils in the Indo-Pacific Warm Pool: a refuge for thermophilic dinoflagellates during glaciations. Geology 42, 531534.

Mertens, K.N., Gu, H., Pospelova, V., Chomérat, N., Nézan, E., Gurdebeke, P.R., Bogus, K., Vrielinck, H., Rumebe, M., Meteigner, C., 2017a. First record of resting cysts of the benthic dinoflagellate Prorocentrum leve in a natural reservoir in Gujan-Mestras, Gironde, France. Journal of Phycology 53, 1193-1205. 
Mertens, K.N., Gu, H., Takano, Y., Price, A.M., Pospelova, V., Bogus, K., Versteegh, G.J.M., Marret, F., Turner, R.E., Rabalais, N.N., Matsuoka, K., 2017b. The cyst-theca relation of Trinovantedinium pallidifulvum, with erection of Protoperidinium lousianensis sp. nov. and their phylogenetic position within the Conica group. Palynology 41, 183-202.

Mertens, K.N., Takano, Y., Gu, H., Bagheri, S., Pospelova, V., Pieńkowski, A.J., Leroy, S., Matsuoka, K., 2017c. Cyst-theca relationship and phylogenetic position of Impagidinium caspienense incubated from Caspian Sea surface sediments: evidence for heterospory within gonyaulacoid dinoflagellates. Journal of Eukaryotic Microbiology 64, 829-842.

Mertens, K.N., Carbonell-Moore, M.C., Pospelova, V., Head, M.J., Highfield, A., Schroeder, D., Gu, H., Andre, K.B., Fernandez, M., Yamaguchi, A., Takano, Y., Matsuoka, K., Nézan, E., Bilien, G., Okolodkov, Y., Koike, K., Hoppenrath M., Pfaff, M., Pitcher, G., Al-Muftah, A., Rochon, A., Lim, P.T., Leaw, C.P., Lim, Z.F., Ellegaard, M., 2018. Pentaplacodinium saltonense gen. et sp. nov. (Dinophyceae) and its relationship to the cyst-defined genus Operculodinium and yessotoxin-producing Protoceratium reticulatum. Harmful Algae 77, 57-77.

Metcalf, J. L., Ursell, L. K., Knight, R., 2014. Ancient human oral plaque preserves a wealth of biological data. Nature Genetics 46, 321-323.

Meyer, M., Kircher, M., Gansauge M. T., et al., 2012. A high-coverage genome sequence from an archaic Denisovan individual. Science 338, 222-226.

Mitchell, K. J., Llamas, B., Soubrier, J., Rawlence, N. J., Worthy, T. H., Wood, J., Lee, M.S.Y., Cooper, A., 2014. Ancient DNA reveals elephant birds and kiwi are sister taxa and clarifies ratite bird evolution. Science 344, 898-900.

Moldowan, J. M., Dahl, J., Jacobson, S. R., Huizinga, B. J., Fago, F. J., Shetty, R., Watt, D. S., Peters, K. E. 1996. Chemostratigraphic reconstruction of biofacies: molecular evidence linking cyst-forming dinoflagellates with pre-Triassic ancestors. Geology 24, 159-162.

Moldowan, J.M., Talyzina, N.M., 1998. Biogeochemical evidence for dinoflagellate ancestors in the Early Cambrian. Science 281, 1168-1170.

Monteil, E., 1992a. Quelques nouvelles espèces-index de kystes de Dinoflagellés (TithoniqueValanginien) du Sud-Est de la France et de l'Ouest de la Suisse. Revue de Paléobiologie,

Genève 11, 273-297.

Monteil, E., 1992b. Kystes de Dinoflagellés index (Tithonique-Valanginien) du Sud-Est de la France. Proposition d'une nouvelle zonation palynologique. Revue de Paléobiologie, Genève 11, 299-306.

Monteil, E., 1993. Dinoflagellate cyst biozonation of the Tithonian and Berriasian of SouthEast France. Correlation with the Sequence stratigraphy. Bulletin du Centre de Recherche Exploration-Production Elf-Aquitaine 17, 249-273.

Montresor, M, Procaccini, G, Stoecker, DK, 1999. Polarella glacialis gen. nov., sp. nov. (Dinophyceae): Suessiaceae are still alive! Journal of Phycology 35, 186-197. 
Montresor, M., Sgrosso, S., Procaccini, G., Kooistra, W.H.C.F., 2003. Intraspecific diversity in Scrippsiella trochoidea (Dinophyceae): evidence for cryptic species. Phycologia 42, 56-70.

Mudie, P.J., Marret, F., Mertens, K.N., Shumilovskikh, L., Leroy, S.A.G., 2017. Atlas of modern dinoflagellate cyst distributions in the Black Sea Corridor: from Aegean to Aral Seas, including Marmara, Black, Azov and Caspian Seas. Marine Micropaleontology 134, 1-152.

Nixon, S.W., 1995. Coastal marine eutrophication: a definition, social causes, and future concerns. Ophelia 41, 199-219.

Nordli, O. 1951. Dinoflagellates from Lofoten. Nytt Magazin for Naturvidenskabene 88, 4955 .

Norris, G., 1978. Phylogeny and a revised suprageneric classification for Triassic-Quaternary organic-walled dinoflagellate cysts (Pyrrhophyta). Part II. Families and sub-orders of fossil dinoflagellates. Neues Jahr. Geol. Paläontologie, Abh 156, 1-30.

Norris, G., Sarjeant, W.A.S., 1965. A descriptive index of genera fossil Dinophyceae and Acritarcha. New Zealand Geol. Survey Paleont. Bull. 40, 42 pp.

Ogg, J.G., Ogg, G.M., Gradstein, F.M., 2008. Geological time scale foundation, Mesozoic and Cenozoic educational charts.

https://engineering.purdue.edu/Stratigraphy/charts/educational.html

Okamoto, O.K., Colepicolo, P., 1998. Response of superoxide dismutase to pollutant metal stress in the marine dinoflagellate Gonyaulax polyedra. Comparative Biochemistry and Physiology Part C: Pharmacology, Toxicology and Endocrinology 119, 67-73.

Orlando, L., Ginolhac, A., Zhang, G., Froese, D., Albrechtsen, A., Stiller, M., et al., 2013. Recalibrating Equus evolution using the genome sequence of an early Middle Pleistocene horse. Nature 499, 74-78.

Orr, R.J.S., Murray, S.A., Stüken, A., Rhodes, L., Jakobsen, K.S., 2012. When naked became armoured: an eight-gene phylogeny reveals monophyletic origin of theca in dinoflagellates. PLoS ONE 7, e50004.

Parducci, L., Matetovici, I., Fontana, S. L., Bennett, K. D., Suyama, Y., Haile, J., Kjaer, K.H., Larsen, N.K., Drouzas, A.D., Willerslev, E., 2013. Molecular- and pollen-based vegetation analysis in lake sediments from central Scandinavia. Molecular Ecology 22, 3511-3524.

Pawlowska, J., Lejzerowicz, F., Esling, P., Szczuciński, W., Zajączkowski, M., Pawlowski, J., 2014. Ancient DNA sheds new light on the Svalbard foraminiferal fossil record of the last millennium. Geobiology 12, 277-288.

Pedersen, M. W., Ginolhac, A., Orlando, L., Olsen, J., Andersen, K., Holm, J., Funder, S., Willerslev, E., Kjær, K. H., 2013. A comparative study of ancient environmental DNA to pollen and macrofossils from lake sediments reveals taxonomic overlap and additional plant taxa. Quaternary Science Reviews 75, 161-168. 
Penaud, A., Eynaud, F., Turon, J. L., Zaragosi, S., Malaizé, B., Toucanne, S., Bourillet, J. F., 2009. What forced the collapse of European ice sheets during the last two glacial periods (150 ka B.P. and 18 ka cal B.P.)? Palynological evidence, Palaeogeography, Palaeoclimatology, Palaeoecology 281, 66-78.

Penaud, A., Eynaud, F., Turon, J. L., Blamart, D., Rossignol, L., Marret, F., Lopez-Martinez, C., Grimalt, J. O., Malaizé, B. Charlier, K., 2010. Contrasting paleoceanographic conditions off Morocco during Heinrich events (1 and 2) and the Last Glacial Maximum. Quaternary Science Reviews 29, 1923-1939.

Penaud, A., Eynaud, F., Voelker, A., Kageyama, M., Marret, F., Turon, J. L., Blamart, D., Mulder, T., Rossignol, L., 2011. Assessment of sea surface temperature changes in the Gulf of Cadiz during the last $30 \mathrm{ka}$ : Implications for glacial changes in the regional hydrography. Biogeosciences 8, 2295-2316, doi:10.5194/bg-8-2295-2011.

Penaud, A., Eynaud, F., Voelker, A.H.L., Turon, J-L., 2016. Palaeohydrological changes over the last $50 \mathrm{kyr}$ in the central Gulf of Cadiz: complex forcing mechanisms mixing multi-scale processes. Biogeosciences 13, 5357-5377.

Persson, A., Godhe, A., Karlson, B., 2000. Dinoflagellate cysts in recent sediments from the west coast of Sweden. Botanica Marina 43, 69-79.

Pietramellara, G., Ascher, J., Borgogni, F., Ceccherini, M. T., Guerri, G., Nannipieri, P., 2009. Extracellular DNA in soil and sediment: fate and ecological relevance. Biology and Fertility of Soils 45, 219-235.

Poinar, H. N., Hofreiter, M., Spaulding, W. G., Martin, P. S., Stankiewicz, B. A., Bland, H., Evershed, R.P., Possnert, G., Pääbo, S., 1998. Molecular coproscopy: dung and diet of the extinct ground sloth Nothrotheriops shastensis. Science 281, 402-406.

Pospelova, V., Kim, S.J., 2010. Dinoflagellate cysts in recent estuarine sediments from aquaculture sites of southern South Korea. Marine Micropaleontology 76, 37-51.

Pospelova, V., Chmura, G., Boothman, W., Latimer, J., 2005. Spatial distribution of modern dinoflagellate cysts in polluted estuarine sediments from Buzzards Bay (Massachusetts, USA) embayments. Marine Ecology Progress Series 292, 23-40.

Pospelova, V., Chmura, G.L., Walker, H.A., 2004. Environmental factors influencing the spatial distribution of dinoflagellate cyst assemblages in shallow lagoons of southern New England (USA). Review of Palaeobotany and Palynology 128, 7-34.

Pospelova, V., Chmura, G.L., Boothman, W.S., Latimer, J.S., 2002. Dinoflagellate cyst records and human disturbance in two neighboring estuaries, New Bedford Harbor and Apponagansett Bay, Massachusetts (USA). Science of the Total Environment 298, 81-102.

Powell, A.J., 1992a. Dinoflagellate cysts of the Triassic System. In: Powell A.J. (Ed.) A Stratigraphic index of dinoflagellate cysts. British Micropalaeontological Society Series. Chapman \& Hall, London, 1-6. 
Powell, A.J., 1992b. Dinoflagellate cysts of the Tertiary System. In: Powell A.J. (Ed.) A Stratigraphic index of dinoflagellate cysts. British Micropalaeontological Society Series. Chapman \& Hall, London, 155-229.

Prebble, J.G., Crouch, E.M., Carter, L., Cortese, G., Bostock, H., Neil, H., 2013. An expanded modern dinoflagellate cyst dataset for the Southwest Pacific and Southern Hemisphere with environmental associations. Marine Micropaleontology 101, 33-48.

Prentice, I.C., 1980. Multidimensional scaling as a research tool in quaternary palynology: A review of theory and methods. Review of Palaeobotany and Palynology 31, 71-104.

Price, D.C., Bhattacharya, D. 2017. Robust dinoflagellate phylogeny inferred from public transcriptome databases. Journal of Phycology 53, 725-729.

Price, A.M., Pospelova, V., 2011. High-resolution sediment trap study of organic-walled dinoflagellate cyst production and biogenic silica flux in Saanich Inlet (BC, Canada). Marine Micropaleontology 80, 18-43.

Price, A.M., Pospelova, V., Coffin, M.R.S., Latimer, J.S., Chmura, G.L., 2016. Biogeography of dinoflagellate cysts in northwest Atlantic estuaries. Ecology and Evolution 6, 5648-5662.

Price, A.M., Baustian, M.M., Turner, R.E., Rabalais, N.N., Chmura, G.L., 2017a. Melitasphaeridium choanophorum - a living fossil dinoflagellate cyst in the Gulf of Mexico. Palynology 41, 351-358. doi:10.1080/01916122.2016.1205676.

Price, A.M., Coffin, M.R., Pospelova, V., Latimer, J.S., Chmura, G.L., 2017b. Effect of nutrient pollution on dinoflagellate cyst assemblages across estuaries of the NW Atlantic. Marine pollution bulletin 121, 339-351.

Pross, J., Brinkhuis, H., 2005. Organic-walled dinoflagellate cysts as paleoenvironmental indicators in the Paleogene; a synopsis of concepts. Paläontologische Zeitschrift 79, 53-59.

Rabalais, N.N., 2002. Nitrogen in aquatic ecosystems. AMBIO: A Journal of the Human Environment 31, 102-112.

Rabalais, N.N., Turner, R.E., Diaz, R.J., Justić, D., 2009. Global change and eutrophication of coastal waters. ICES Journal of Marine Science 66, 1528-1537.

Radi, T., de Vernal, A., 2004. Dinocyst distribution in surface sediments from the northeastern Pacific margin $\left(40-60^{\circ} \mathrm{N}\right)$ in relation to hydrographic conditions, productivity and upwelling. Review of Palaeobotany and Palynology 128, 169-193.

Radi, T., de Vernal, A., 2008. Dinocysts as proxy of primary productivity in mid-high latitudes of the Northern Hemisphere. Marine Micropaleontology 68, 84-114. https://doi.org/10.1016/j.marmicro.2008.01.012

Radi, T., Bonnet, S., Cormier, M. A., de Vernal, A., Durantou, L., Faubert, É., Head, M. J., Henry, M., Pospelova, V., Rochon, A., Van Nieuwenhove, N., 2013. Operational taxonomy and (paleo-)autecology of round, brown, spiny dinoflagellate cysts from the Quaternary of high northern latitudes. Marine Micropaleontology 98, 41-57. 
Rahman, A., 1995. Reworked nannofossils in the North Atlantic Ocean and subpolar basins: implications for Heinrich events and ocean circulation. Geology 23, 487-490.

Rahmstorf, S., 2002. Ocean circulation and climate during the past 120,000 years. Nature 419, 207-214.

Rasmussen, T. L., Thomsen, E., 2004. The Role of the North Atlantic Drift in the Millennial Timescale Glacial Climate Fluctuations." Palaeogeography, Palaeoclimatology, Palaeoecology 210, 101-16.

Reguera, B., Velo-Suarez, L., Raine, R., Park, M.G., 2012. Harmful Dinophysis species: A review. Harmful Algae 14, 87-106.

Reinsch, P. F., 1905. Die Palinosphärien, ein mikroskopischer vegetabile Organismus in der Mukronatenkreide. Centralbl. Mineralogie, Geologie, Palaeontologie, Jahrg. 1905, 26-31.

Rochon, A., de Vernal, A., Turon, J.-L., Matthiessen, J., Head, M.J., 1999. Distribution of recent dinoflagellate cysts in surface sediments from the North Atlantic Ocean and adjacent seas in relation to sea-surface parameters. AASP Contribution Series, 35, $146 \mathrm{pp}$.

Rochon, A., Lewis, J., Ellegaard, M., Harding, I.C., 2009. The Gonyaulax spinifera (Dinophyceae) "complex": perpetuating the paradox? Review of Palaeobotany and Palynology 155, 52-60.

Sætre, M.M., Dale, B., Abdullah, M.I., Sætre, G.P., 1997.Dinoflagellate cysts as potential indicators of industrial pollution in a Norwegian fjord. Marine Environmental Research 44, 167-189.

Saldarriaga, J.F., Taylor, F.J.R. "Max", Cavalier-Smith, T., Menden-Deuer, S., Keeling, P.J., 2004. Molecular data and the evolutionary history of dinoflagellates. European Journal of Protistology 40, 85-111.

Sampedro, N., Fraga, S., Penna, A., Casabianca, S., Zapata, M., Grünewald, C.F., Riobo, P., Camp, J., 2011. Barrufeta bravensis gen. nov. sp. nov. (Dinophyceae): a new bloom-forming species from the northwest Mediterranean Sea. Journal of Phycology 47, 375-392.

Sangiorgi, F., Donders, T.H., 2004. Reconstructing 150 years of eutrophication in the northwestern Adriatic Sea (Italy) using dinoflagellate cysts, pollen and spores. Estuarine Coastal and Shelf Science 60, 69-79.

Sarjeant, W.A.S., 1965. Microplankton from the Callovian (S. calloviense Zone) of Normandy. Revue de micropaléontologie 8, 175-184.

Sarjeant, W.A.S., 1974. Fossil and Living Dinoflagellates. London, UK: Academic Press Inc., $182 \mathrm{pp}$.

Sarjeant, W.A.S., 1978. Arpylorus antiquus Calandra, emend., a dinoflagellate cyst from the Upper Silurian. Palynology 2, 176-179. 
Sarjeant, W.A.S., 1979. Middle and Upper Jurassic dinoflagellate cysts: the world excluding North America. American Association of Stratigraphic Palynologists, Contributions Series 5B, 133-157.

Schiebel, R., Waniek, J., Bork, M., Hemleben, C., 2001. Planktic foraminiferal production stimulated by chlorophyll redistribution and entrainment of nutrients. Deep-sea Research. Part I, Oceanographic Research Papers 48, 721-740.

Schreck, M., Nam, S.I., Clotten, C., Fahl, K., De Schepper, S., Forwick, M., Matthiessen, J., 2017. Neogene dinoflagellate cysts and acritarchs from the high northern latitudes and their relation to sea surface temperature. Marine Micropaleontology 136, 51-65.

Servais ,T., Eiserhardt, K.H., 1995. A discussion and proposals concerning the Lower Paleozoic 'galeate' acritarch plexus. Palynology 19, 191-210.

Servais, T., Stricanne, L., Montenari M., Pross, J., 2004. Population dynamics of Galeate acritarchs at the Cambrian-Ordovician transition in the Algerian Sahara. Palaeontology 47, 395-414.

Shapiro, B., 2004. Rise and Fall of the Beringian Steppe Bison. Science 306, 1561-1565

Shin, H.H., Mizushima, K., Oh, S.J., Park, J.S., Noh, I.H., Iwataki, M., Matsuoka, K., Yoon, Y.H., 2010. Reconstruction of historical nutrient levels in Korean and Japanese coastal areas based on dinoflagellate cyst assemblages. Marine Pollution Bulletin 60, 1243-1258.

Smayda, T.J., 2008. Complexity in the eutrophication-harmful algal bloom relationship, with comment on the importance of grazing. Harmful Algae 8, 140-151.

Stosch, H.A. von, 1964. Zum Problem der sexuellen Fortpflanzung in der Peridineengattung Ceratium. Helgoländer wissenschaftliche Meeresuntersuchungen 10, 140-152.

Stosch, H.A. von, 1965. Sexualität bei Ceratium cornutum (Dinophyta). Die Naturwissenschaften 52, 112-113.

Stosch, H.A. von, 1972. La signification cytologique de la "cyclose nucleaire" dans le cycle de vie des dinoflagellés. Colloque sur les cycles sexuels et l'alternance des générations chez les Algues. Paris (1970). Mémoires publiés par la Société botanique de France, 201-212.

Stoch, H.A. von, 1973. Observations on vegetative reproduction and sexual life cycles of two freshwater dinoflagellates, Gymnodinium pseudopalustre Schiller and Woloszynskia apiculata sp. nov. British Phycological Journal 8, 105-134.

Stover, L.E., Evitt, W.R., 1978. Analyses of pre-Pleistocene organic-walled dinoflagellates. Standford University Publications, Geological Sciences 15, 300 pp.

Takahashi, K., Honjo, S., 1981. Vertical Flux of Radiolaria: A Taxon-Quantitative Sediment Trap Study from the Western Tropical Atlantic. Micropaleontology 27, 140. 
Talyzina, N.M., Moldowan, J.M., Johannisson, A., Fago, F.J., 2000. Affinities of Early Cambrian acritarchs studied by using microscopy, fluorescence flow cytometry and biomarkers. Review of Palaeobotany and Palynology 108, 37-53.

Taylor, F.J.R., 1980. On dinoflagellate evolution. BioSystems 13, 65-108.

Taylor, F.J.R., Fukuyo, Y., Larsen, J., 1995. Taxonomy of harmful dinoflagellates. In: Hallegraeff GM, Anderson DM, Cembella AD, editors. Manual on Harmful Marine Microalgae. IOC Manuals and Guides No. 33. Paris: UNESCO, 283-317.

Telford, R.J., Andersson, C., Birks, H.J.B., Juggins, S., 2004. Biases in the estimation of transfer function prediction errors. Paleoceanography, 19, PA4014.

Telford, R.J., Birks, H.J.B., 2005. The secret assumption of transfer functions: problems with spatial autocorrelation in evaluating model performance. Quaternary Science Reviews 24, $2173-2179$.

Telford, R.J., 2006. Limitations of dinoflagellate cyst transfer functions. Quaternary Science Reviews 25, 1375-1382.

Telford, R.J., Birks, H.J.B., 2009. Evaluation of transfer functions in spatially structured environments. Quaternary Science Reviews 28, 1309-1316

Telford, R.J., Birks, H.J.B., 2011. QSR Correspondence "Is spatial autocorrelation introducing biases in the apparent accuracy of palaeoclimatic reconstructions?". Quaternary Science Reviews 30, 3210-3213.

Thorsen, T.A., Dale, B., 1997. Dinoflagellate cysts as indicators of pollution and past climate in a Norwegian fjord. The Holocene 7, 433-446.

Tian, C., Doblin, M.A., Dafforn, K.A., Johnston, E.L., Pei, H., Hu, W., 2018. Dinoflagellate cyst abundance is positively correlated to sediment organic carbon in Sydney Harbour and Botany Bay, NSW, Australia. Environmental Science and Pollution Research 25, 5808-5821.

Tilman, D., May, R.M., Lehman, C.L., Nowak, M.A., 1994. Habitat destruction and the extinction debt. Nature 371, 65.

Tollefson, J., 2017. Giant crack in Antarctic ice shelf spotlights advances in glaciology. Nature 542, 402-403.

Torti, A., Lever, M. A., Jørgensen, B. B., 2015. Origin, dynamics, and implications of extracellular DNA pools in marine sediments. Marine Genomics 24, 185-196.

Triki, H.Z., Laabir, M., Lafabrie, C., Malouche, D., Bancon-Montigny, C., Gonzalez, C., Deidun, A., Pringault, O., Daly-Yahia, O.K., 2017. Do the levels of industrial pollutants influence the distribution and abundance of dinoflagellate cysts in the recently-deposited sediment of a Mediterranean coastal ecosystem? Science of the Total Environment 595, 380 392. 
Turner, R.E., Rabalais, N.N., 1994. Coastal eutrophication near the Mississippi river delta. Nature 368, 619.

Turon, J.L., 1984. Le palynoplancton dans l'environnement actuel de l'Atlantique Nordoriental. Evolution climatique et hydrologique depuis le dernier maximum glaciaire. Mémoires de l'Institut de Géologie du Bassin d'Aquitaine 17, 313 pp.

Turon, J.L., Lézine, A.M., Denèfle, M., 2003. Land-sea correlations for the last glaciation inferred from a pollen and dinocyst record from the Portuguese margin. Quaternary Research $59,88-96$.

Vail, P., Mitchum, R., Thompson, S. III., 1977. Seismic stratigraphy and global changes of sea level, Part 4: global cycles of relative changes of sea level. In: Payton, C.E., (Ed.). Seismic stratigraphy: applications to hydrocarbon exploration. American Association of Petroleum Geologists, Memoir 26, 83-97.

Van Hinte, J., 1976a. A Jurassic timescale. American Association of Petroleum Geologists, Bulletin 60, 498-516.

Van Hinte, J., 1976b. A Cretaceous timescale. American Association of Petroleum Geologists, Bulletin 60, 489-497.

Verleye, T.J., Louwye, S., 2010. Late Quaternary environmental changes and latitudinal shifts of the Antarctic Circumpolar Current as recorded by dinoflagellate cysts from offshore Chile ( $\left.41^{\circ} \mathrm{S}\right)$. Quaternary Science Reviews 29, 1025-1039.

Vink, A., Rühlemann, C., Zonneveld, K.A F; Mulitza, S., Hüls, M., Willems, H., 2001. Shifts in the Position of the North Equatorial Current and Rapid Productivity Changes in the western Tropical Atlantic during the Last Glacial. Paleoceanography 16, 479-490

Voelker, A. H., 2002. Global distribution of centennial-scale records for Marine Isotope Stage (MIS) 3: a database. Quaternary Science Reviews 21, 1185-1212.

Vozzhennikova, T.F., 1967. Iskopaemye peridinei yurskikh, melovykh i paleogenovykh otlozhenii SSSR. Moscow Akad. Nauk. Sibirskoe Otdelenie, Inst. Geologii Geofisiki 300 pp.

Wall, D., 1965. Modern hystrichospheres and dinoflagellate cysts from the Woods Hole region. Grana Palynologica 6, 297-314.

Wall, D., Dale, B. 1966. "Living fossils" in Western Atlantic plankton. Nature (London) 211, $1025-1026$.

Wall, D., Dale, B., 1968. Modern dinoflagellate cysts and evolution Peridiniales.

Micropaleontology 14, 265-304.

Wall, D., Evitt, W.R., 1975. A comparison of the modern genus Ceratium Schrank, 1793, with certain Cretaceous marine dinoflagellates. Micropaleontology 24, 14-44. 
Wall, D., Dale, B., Lohmann, G.P., Smith, W.K., 1977. The environment and climatic distribution of dinoflagellate cysts in modern marine sediments from regions in the north and south Atlantic oceans and adjacent seas. Marine Micropaleontology 2, 121-200.

Wary, M., Eynaud, F., Kissel, C., Londeix, L., Rossignol, L., Lapuyade, J., Castéra, M.-H., Billy, I., 2018. Spatio-temporal dynamics of hydrographic reorganizations and iceberg discharges at the junction between the Northeast Atlantic and Norwegian Sea basins surrounding Heinrich event 4. Earth and Planetary Science Letters 481, 236-245.

Wary, M., Eynaud, F., Rossignol, L., Lapuyade, J., Gasparotto, M.-C., Londeix, L., Malaizé, B., Castéra, M.-H., Charlier, K., 2016. Norwegian Sea warm pulses during DansgaardOeschger stadials: Zooming in on these anomalies over the 35-41 ka cal BP interval and their impacts on proximal European ice-sheet dynamics. Quaternary Science Reviews 151, 255272.

Wary, M., Eynaud, F., Sabine, M., Zaragosi, S., Rossignol, L., Malaizé, B., Palis, E., Zumaque, J., Caulle, C., Penaud, A., Michel, E., Charlier, K., 2015. Stratification of surface waters during the last glacial millennial climatic events: A key factor in subsurface and deepwater mass dynamics. Climate of the Past 11, 1507-1525.

Wary, M., Eynaud, F., Swingedouw, D., Masson-Delmotte, V., Matthiessen, J., Kissel, C., Zumaque, J., Rossignol, L. Jouzel, J., 2017a. Regional seesaw between North Atlantic and Nordic Seas during the last glacial abrupt climate events. Climate of the Past 13, 729-739.

Wary, M., Eynaud, F., Zaragosi, S., Rossignol, L., Sabine, M., Castéra, M.-H., Billy, I., 2017b. The Southern Norwegian Sea during the last 45 ka: hydrographical reorganizations under changing ice-sheet dynamics. Journal of Quaternary Science 32, 908-922.

Wetzel, O., 1933. Die in organischer Substanzerhaltenen Mikrofossilien des baltischen Kreidefeuersteins, mit einem sedimentpetrographischen und stratigraphischen Anhang. Palaeontographica A, 77, 147-188; 78, 47-156.

Willerslev, E., Cooper, A., 2005. Ancient DNA. Proceedings of the Royal Society, Series B, 272, 3-16.

Willerslev, E., Cappellini, E., Boomsma, W., Nielsen, R., Hebsgaard, M. B., Brand, T. B., et al., 2007. Ancient biomolecules from deep ice cores reveal a forested southern Greenland. Science 317, 111-114.

Willerslev, E., Davison, J., Moora, M., Zobel, M., Coissac, E., Edwards, M. E., et al., 2014. Fifty thousand years of Arctic vegetation and megafaunal diet. Nature 506, 47-51.

Willerslev, E., Hansen, A. J., Poinar, H.N., 2004. Isolation of nucleic acids and cultures from fossil ice and permafrost. Trends in Ecology and Evolution 19, 141-147.

Williams, D.B., 1971. The occurrence of dinoflagellates in marine sediments. In: B.M, Funnell and W.R. Riedel (Editors). The Micropalaeontology of the Oceans, Cambridge Univ. Press, Cambridge, 231239. 
Williams, G.L., 1977. Dinocysts. Their classification, biostratigraphy and palaeoecology. In: A.T.S. Ramsay (Editor). Oceanic Micropalaeontology, Academic, New York, 1231-1325.

Williams, G.L., Bujak, J.P., 1986. Mesozoic and Cenozoic Dinoflagellates. In: Hans M. Bolli, H.M., Saunders, J.B., Perch-Nielsen. K. Plankton Stratigraphy 2. Radiolaria, diatoms, silicoflagellates, dinoflagellates and ichthyoliths, Cambridge earth series, University Press, 847-864.

Williams, G.L., Stover, L.E., Kidson, E.J. 1993. Morphology and stratigraphic ranges of selected Mesozoic-Cenozoic dinoflagellate taxa in the northern hemisphere. Geological survey of Canada. Paper 92-10, 137 pp.

Williams, G.L., Brinkhius, H., Pearce, M.A., Fensome, R.A., Weegink, J.W., 2004. Southern Ocean and global dinoflagellate cyst events for the Late Cretaceous-Neogene. In: Exon N.F., Kennett, J.P., Malone, M.J. (Eds). Proc. ODP, Sci. Results 189, 1-98.

Williams, G.L., Fensome, R.A., MacRae, R.A., 2017a. The Lentin and Williams index of fossil dinoflagellates 2017 edition. American Association of Stratigraphic Palynologists Contributions Series no. 48.

Williams, G.L., Fensome, R.A., MacRae, R.A., 2017b. DINOFLAJ3. American Association of Stratigraphic Palynologists, Data Series 2. http://dinoflaj.smu.ca/dinoflaj3

Woollam, R., Riding, J.B., 1983. Dinoflagellate cyst zonation of the English Jurassic. Institute of Geological Sciences, Report 83, 42 pp.

Zaragosi, S., Eynaud, F., Pujol, C., Auffret, G. A., Turon, J. L., Garlan, T., 2001. Initiation of the European deglaciation as recorded in the northwestern Bay of Biscay slope environments (Meriadzek Terrace and Trevelyan Escarpment): A multi-proxy approach. Earth and Planetary Science Letters 188, 493-507.

Zinssmeister, C., Soehner, S., Facher, E., Kirsch, M., Meier, K.J.S., Gottschling, M., 2011. Catch me if you can: the taxonomic identity of Scrippsiella trochoidea (F. Stein) A.R. Loebl. (Thoracosphaeraceae, Dinophyceae). Systematics and Biodiversity 9, 145-157.

Zonneveld, K. A. F., Marret, F., Versteegh, G. J. M., Bogus, K., Bonnet, S., Bouimetarhan, I., Crouch, E., de Vernal, A., Elshanawany, R., Edwards, L., Esper, O., Forke, S., Grøsfjeld, K., Henry, M., Holzwarth, U., Kielt, J. F., Kim, S. Y., Ladouceur, S., Ledu, D., Chen, L., Limoges, A., Londeix, L., Lu, S. H., Mahmoud, M. S., Marino, G., Matsuoka, K., Matthiessen, J., Mildenhal, D. C., Mudie, P., Neil, H. L., Pospelova, V., Qi, Y., Radi, T., Richerol, T., Rochon, A., Sangiorgi, F., Solignac, S., Turon, J. L., Verleye, T., Wang, Y., Wang, Z., Young, M., 2013. Atlas of modern dinoflagellate cyst distribution based on 2405 data points. Review of Palaeobotany and Palynology 191, 1-197.

Zonneveld, K.A., Chen, L., Elshanawany, R., Fischer, H.W., Hoins, M., Ibrahim, M.I., Pittauerova, D., Versteegh, G. J., 2012. The use of dinoflagellate cysts to separate humaninduced from natural variability in the trophic state of the Po River discharge plume over the last two centuries. Marine pollution bulletin 64, 114-132. 
Zonneveld, K.A., P. Hoek, R., Brinkhuis, H., Helmut Willems, 2001. Geographical distributions of organic-walled dinoflagellate cysts in surficial sediments of the Benguela upwelling region and their relationship to upper ocean conditions. Progress in Oceanography $48,25-72$.

Zonneveld, K.A.F., Versteegh, G.J.M., De Lange, G.J., 1997. Preservation of organic walled dinoflagellate cysts in different oxygen regimes: a 10,000 years natural experiment. Marine Micropaleontology 29, 393-405.

Zumaque, J., Eynaud, F., Zaragosi, S., Marret, F., Matsuzaki, K. M., Kissel, C., Roche, D. M., Malaizé, B., Michel, E., Billy, I., Richter, T., Palis, E., 2012. An ocean-ice coupled response during the last glacial: a view from a marine isotopic stage 3 record south of the Faeroe Shetland Gateway. Climate of the Past 8, 1997-2017. 


\section{Table caption}

Table1: List of dinocyst taxa and their acronyms used in Figure 5.

Table 2: List of modern marine environmental parameters implemented in modern databases and used for dinocyst-based quantified reconstructions.

\section{Figure captions}

Figure 1: a) Dinocyst from the mid-Cretaceous Achomosphaera ramulifera (Campanian). Note the archeopyle (precingular) with angular boundaries (plate boundaries). Bifide and trifide processes are located on bifide and triple junctions. Photo: Edwige Masure; b) Galeate acritarch Stelliferidium sp. Note the opening without angular marks and the absence of cingulum and sulcus. Photo: Marco Vecoli. For both pictures: scale bar $=10 \mu \mathrm{m}$.

Figure 2: Location of recently studied modern dinocyst assemblages per atlas, with the spatial distribution and the density of studied sites per latitude.

Figure 3: Latitudinal distribution of the most abundant dinoflagellate cyst taxa from assemblages and diversity. Relative abundance for each species and diversity were averaged in a 5-degree latitudinal band.

Figure 4: Location of modern sites included in dinocyst modern databases used for quantified paleoceanographic reconstructions.

Figure 5: Canonical Correspondence Analyses (CCA) performed with PAST software (Hammer et al., 2001) on Arctic (de Vernal et al., 2013), Tropical Atlantic (Marret et al., 
2008; Hardy et al., 2018) and Southern Oceans (Prebble et al., 2013) modern databases. Taxa acronyms are listed in Table 2. SST: Sea-Surface Temperature; SSS: Sea-Surface Salinity; WOA: World Ocean Atlas.

Figure 6: Hydrographical context of the North Atlantic Ocean and location of the latitudinal transect of cores used in Figure 7. The hatched areas represent the last glacial maximal extent of proximal ice sheets (after Ehlers and Gibbard, 2007). The arrows indicate the major pathways of warm surface waters (yellow) carried by the Gulf Stream northward extensions and cold polar waters (blue). AzC $=$ Azores Current, $\mathrm{PC}=$ Portugal Current, NAD $=$ North Atlantic Drift, NAC $=$ North Atlantic Current, EIC $=$ East Icelandic Current, STG $=$ Subtropical Gyre, SPG = Subpolar Gyre .

Figure 7: Dinocyst data acquired in 4 different cores: MD99-2285 (a-a'), MD95-2002 (b-b'), SU-8118 (c-c'), MD99-2339 (d-d'), located in a north-south transect (cf. Figure 6) in the NE Atlantic Ocean in parallel with Greenland $\delta^{18} \mathrm{O}$ data (NGRIP, GICC05 timescale). Warm/Cold (W/C) index (cf. Penaud et al., 2016 for the species used to establish the ratio).

Figure 8: Comparison between selected palynological data from the I_09 core taken in a highly anthropized estuary (Bay of Brest, Brittany; Lambert et al., 2018), data from ancient DNA measurements (Klouch et al., 2016), and instrumental data from in situ measurements in watersheds. From left to right: XRF Ti/Ca ratio from the study core, measured precipitations and atmospheric temperatures (Rennes meteorological station; infoclimat.fr), measured nitrate fluxes in the Elorn river (SAGE Elorn), dinocyst percentages (Lingulodinium machaerophorum, Spiniferites bentorii, cysts of Pentapharsodinium dalei and Spiniferites membranaceus) and detection curve of Alexandrium minutum species in the same core (from 
Klouch et al., 2016). Limit A corresponds to the first detection of continental runoff increases following the post-World War II land consolidation policy. Limit B corresponds to an increase in continental runoff and the massive introduction of nitrates for agricultural uses. Limit $\mathrm{C}$ highlights the top interval characterized by the preponderance of eutrophication indicators (i.e. nitrates fluxes) and significant changes in the dinoflagellate community: i) specific relay leading to the prominence of $S$. bentorii, $S$. membranaceus and cysts of $P$. dalei, and ii) the sharp increase of the A. minutum signal. 


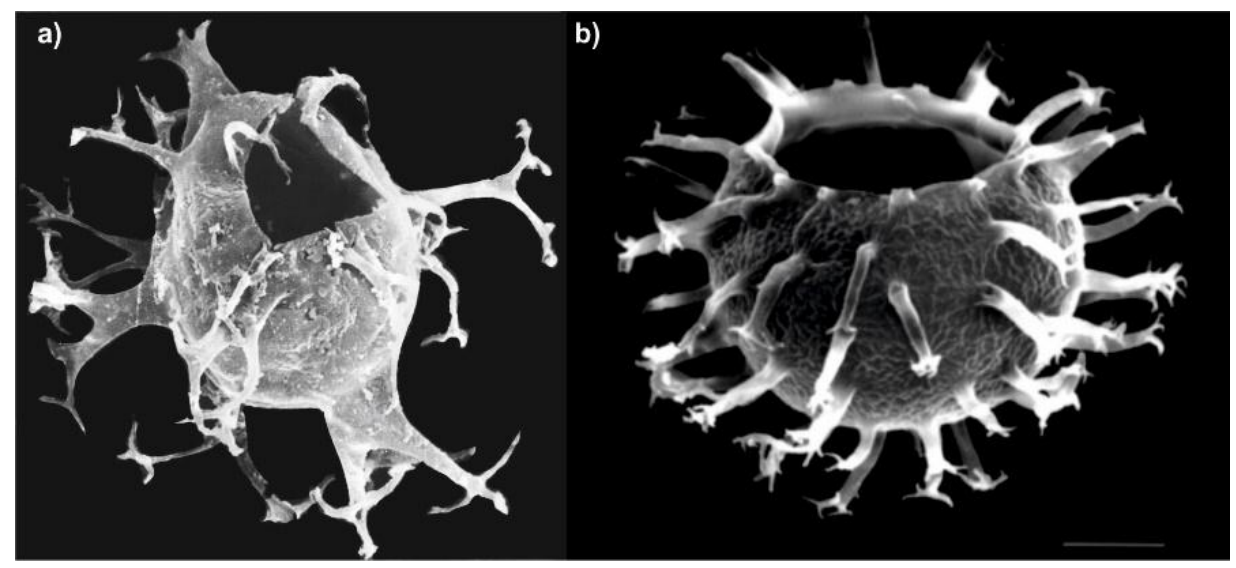

Figure 1

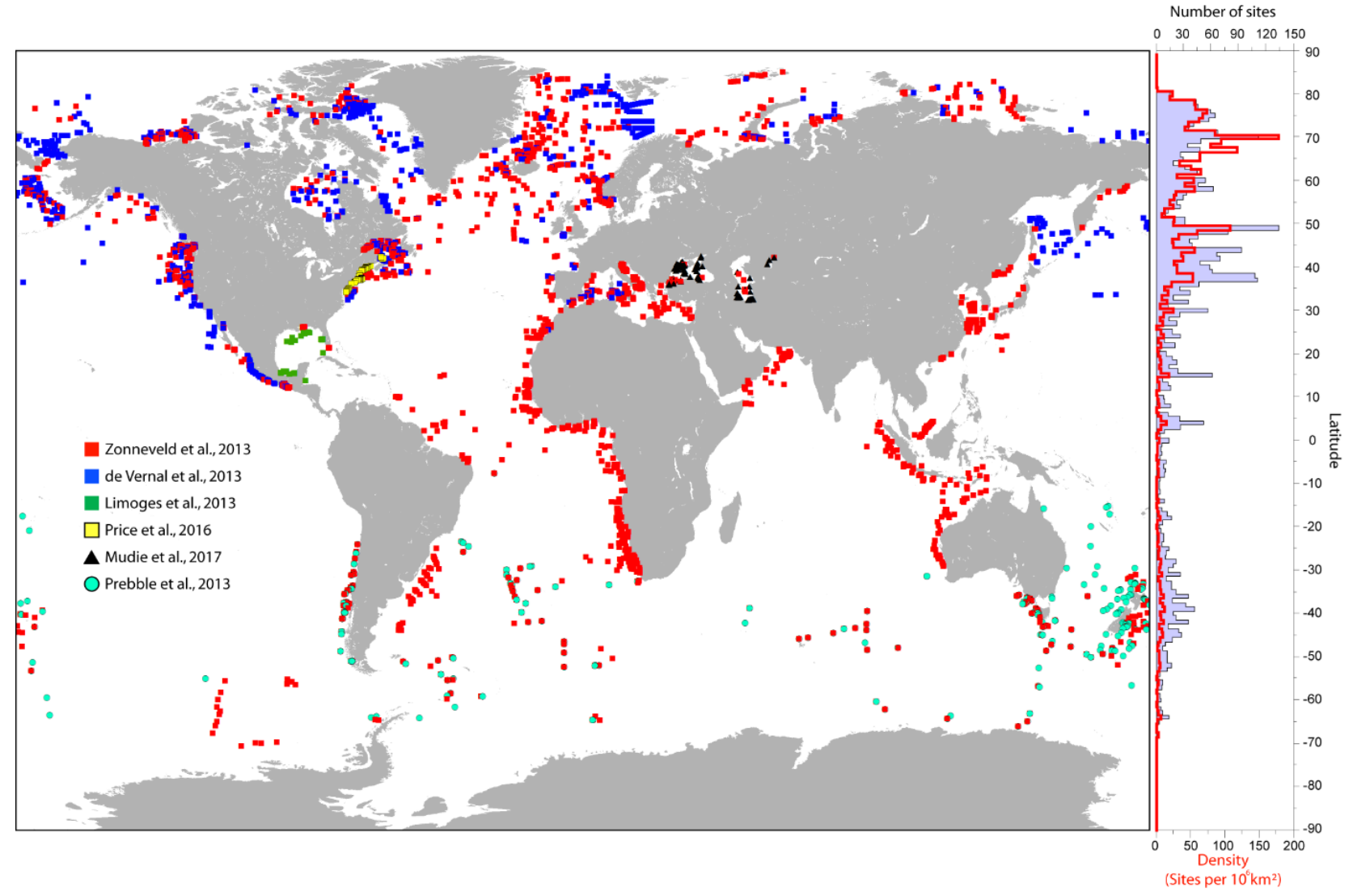

Figure 2 


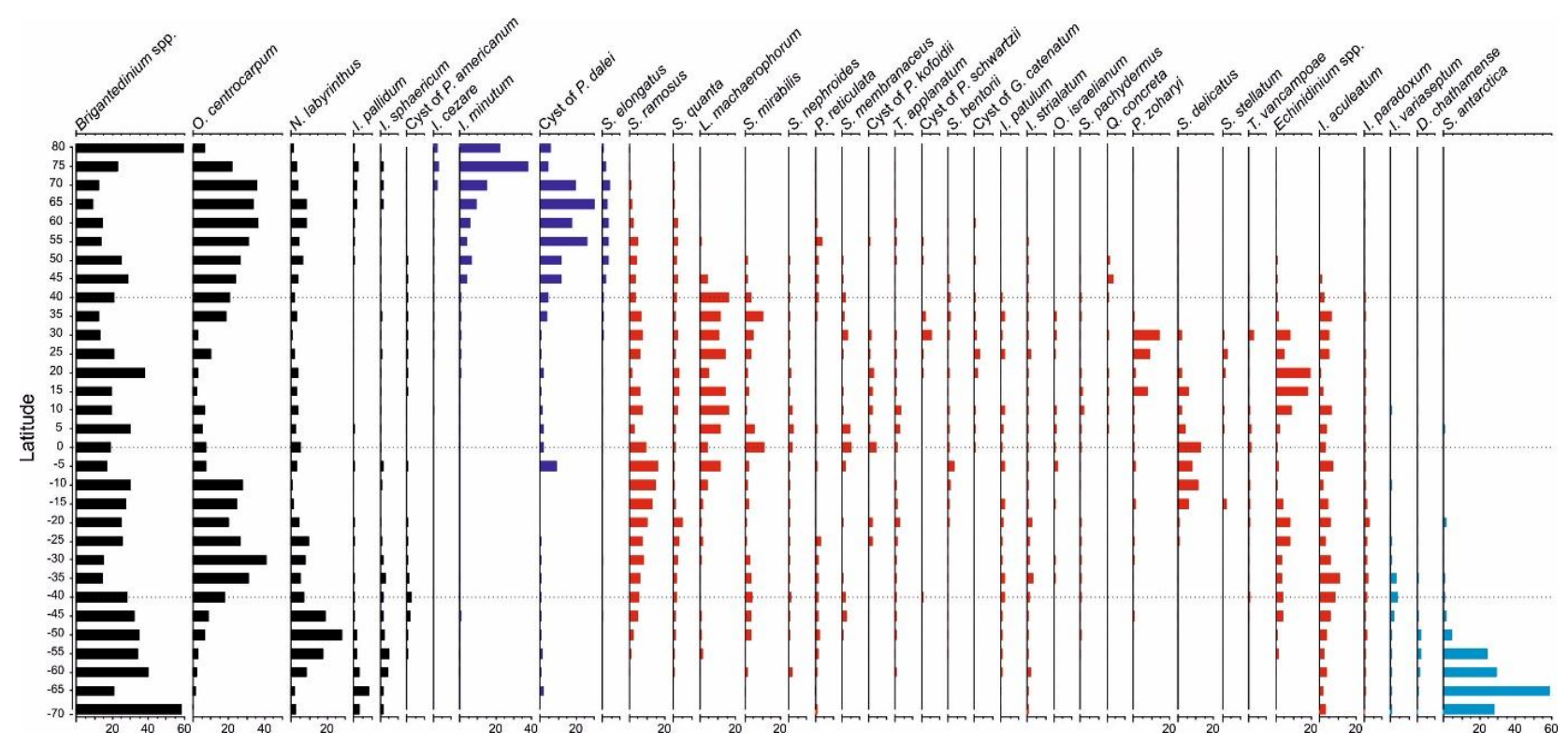

Figure 3

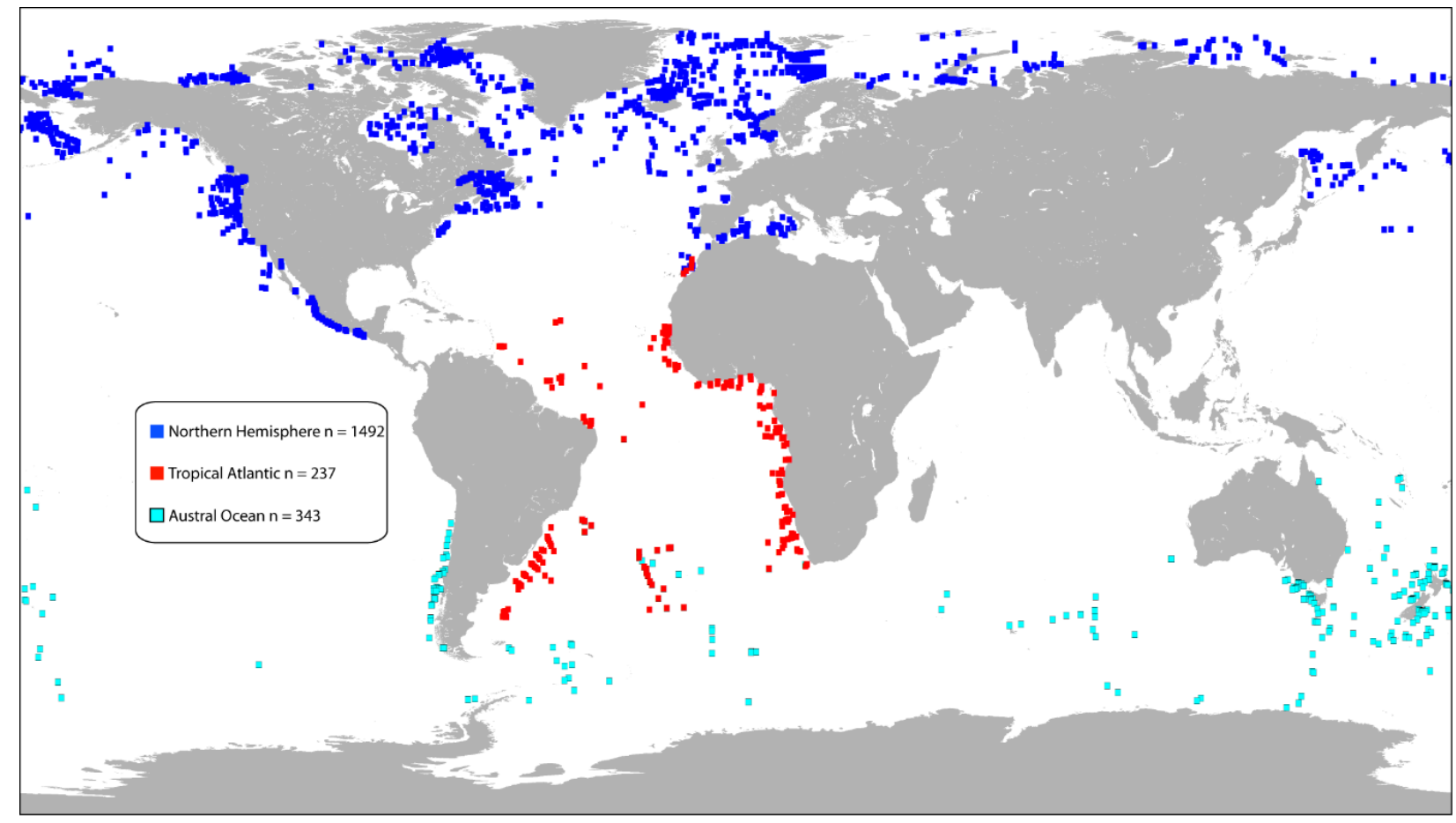

Figure 4 

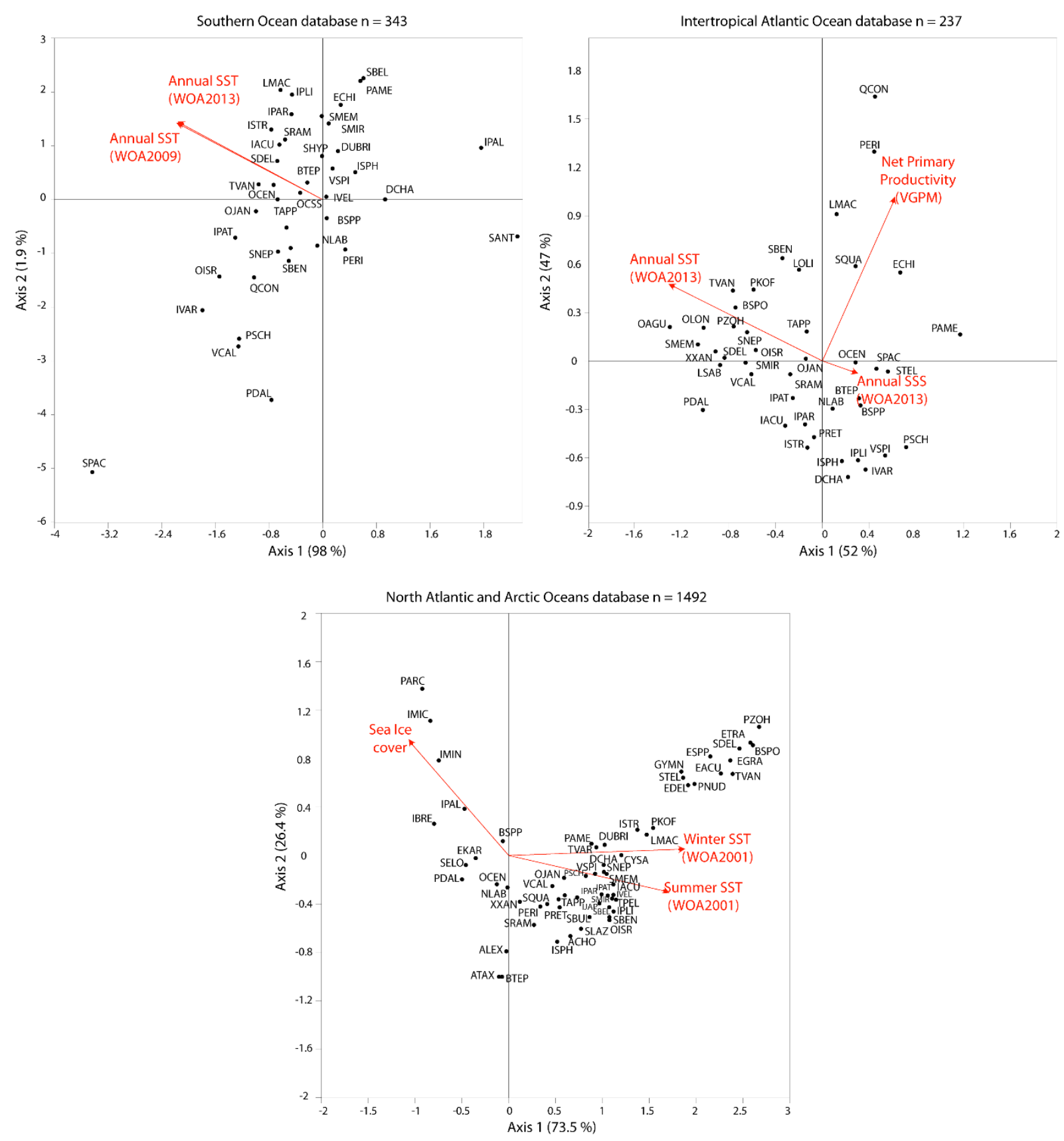

Figure 5 


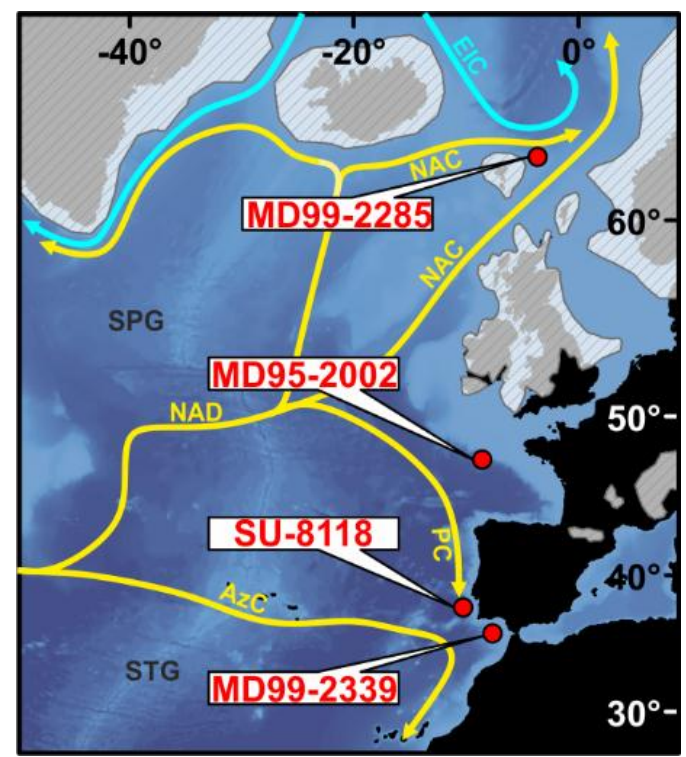

Figure 6

\begin{tabular}{|c|c|c|c|}
\hline $\begin{array}{l}\text { MD99-2285 - a)-a') } \\
\text { Southern Norwegian Sea }\end{array}$ & $\begin{array}{l}\text { MD95-2002 - b)-b') } \\
\text { Bay of Biscay }\end{array}$ & $\begin{array}{l}\text { SU-8118 - c)-c') } \\
\text { Southern Portugal }\end{array}$ & $\begin{array}{l}\text { MD99-2339 - d)-d') } \\
\text { Gulf of Cadiz }\end{array}$ \\
\hline$\%$ dinocysts & $\%$ dinocysts & $\%$ dinocysts & $\%$ dinocysts \\
\hline
\end{tabular}

$\%$ dinocysts
a) Wary et al., 2017a

b) $\%$ dinocysts

$\%$ dinocysts

d) dinocysts

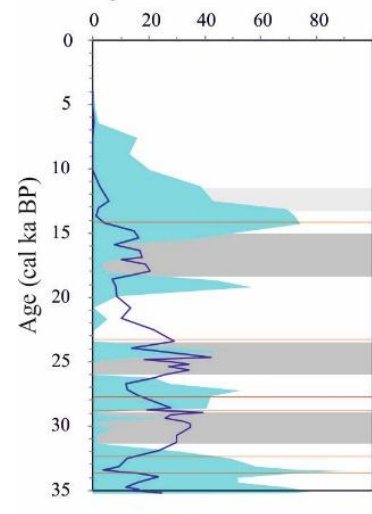

$\begin{array}{lllll}0 & 20 & 40 & 60 & 80\end{array}$

$\begin{array}{lllll}0 & 20 & 40 & 60 & 80\end{array}$
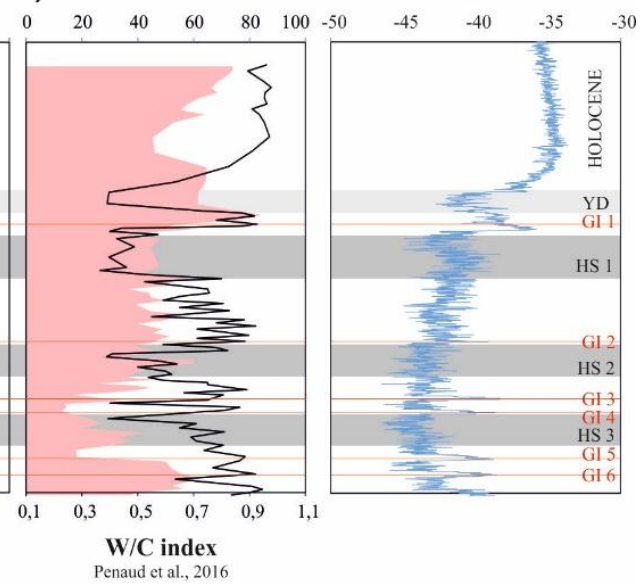

Sea Ice Cover

Sea Surface Temperature
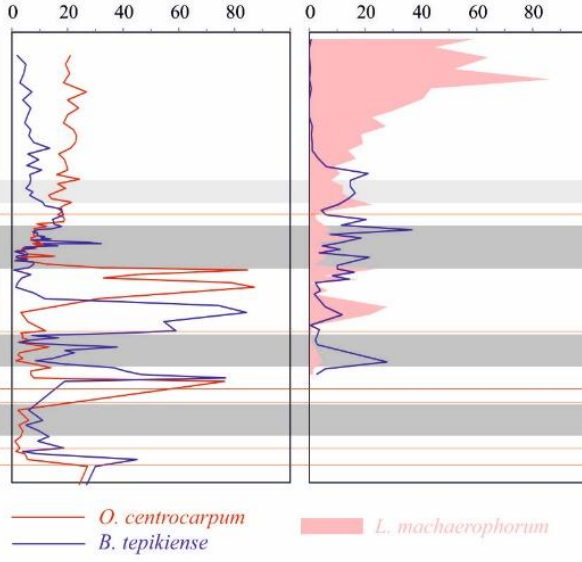

$\delta^{18} \mathrm{O}$ NGRIP

a') Winter $\left({ }^{\circ} \mathrm{C}\right)$

Pre-quaternary cyst concentrations

Heterotroph /Autotroph

Net Primary Productivity

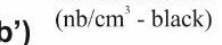
c')

d') $\quad \begin{aligned} & \text { (gC/man et al., } 2016 \\ & \text { Penar }\end{aligned}$ $\delta^{\text {t8 }} \mathrm{O}$ NGRIP
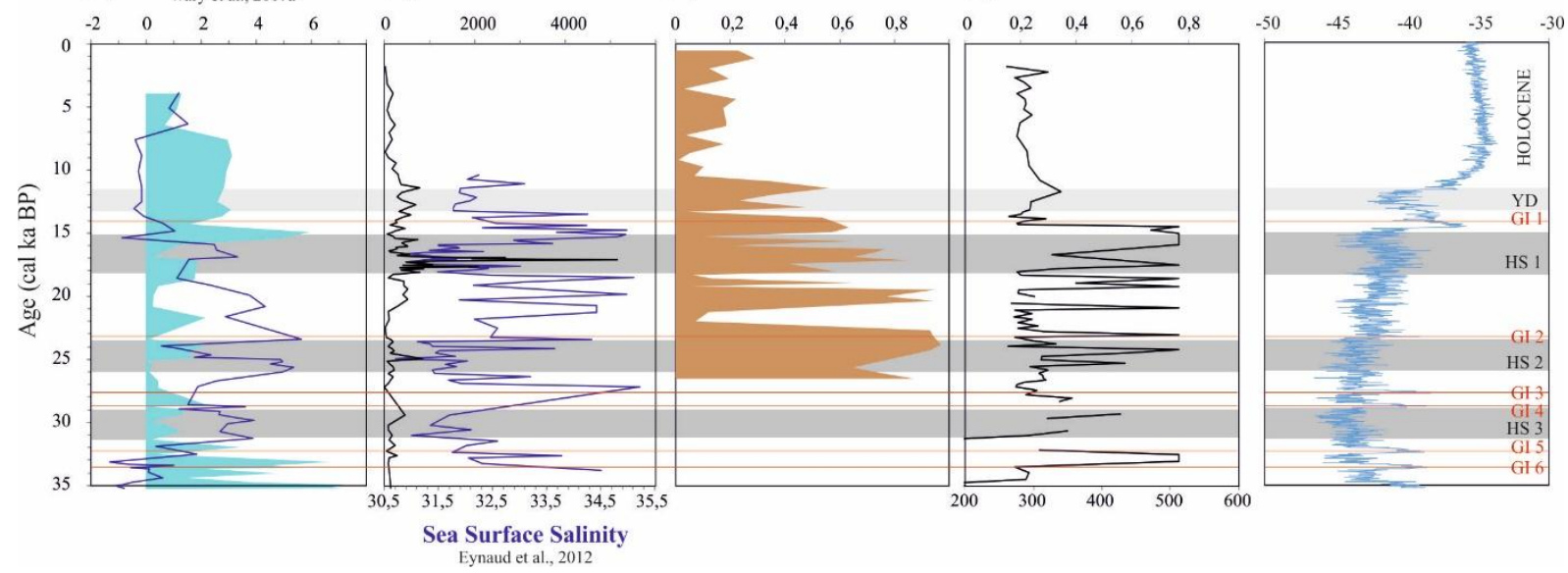

Figure 7 


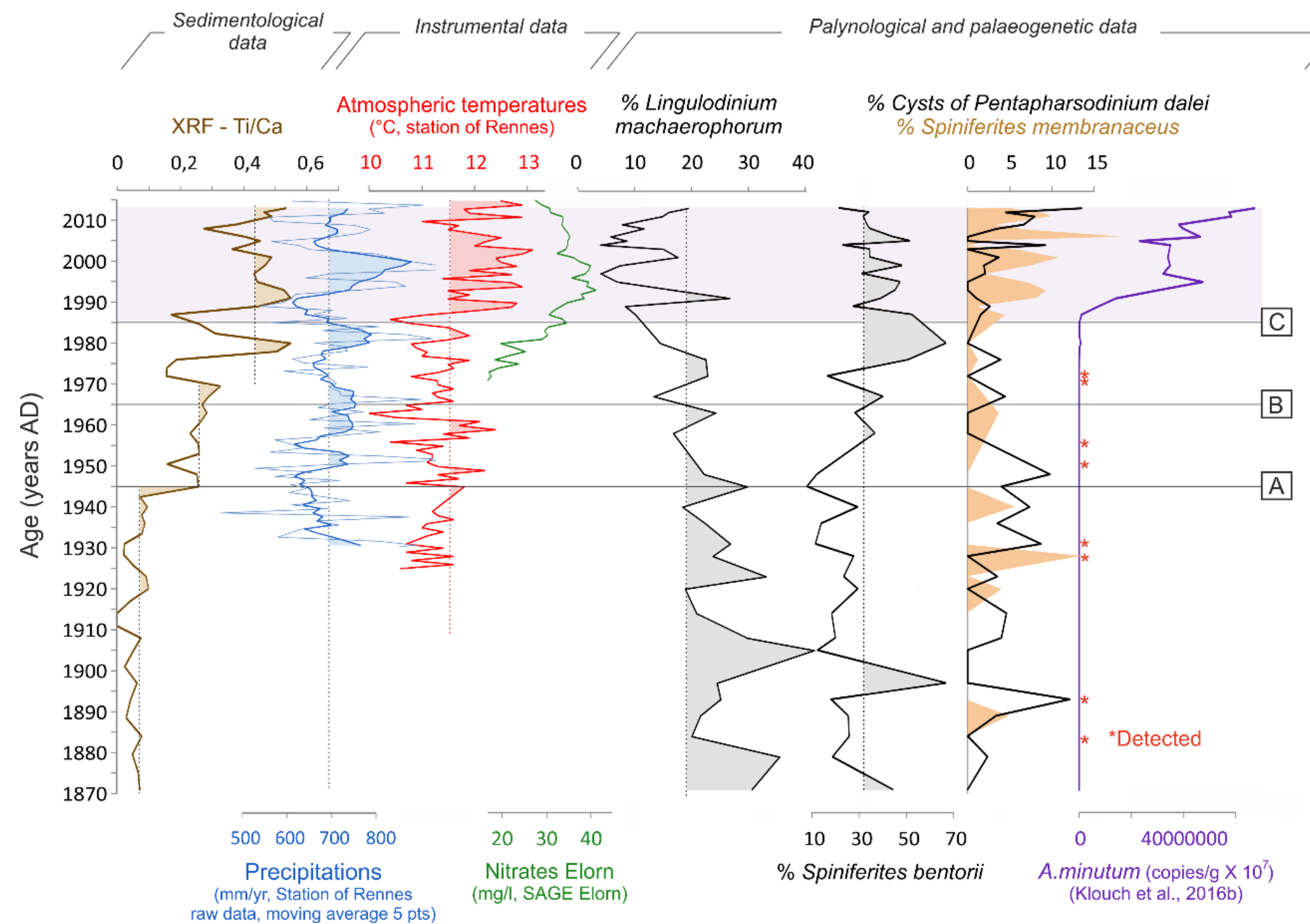




\begin{tabular}{|c|c|c|c|c|}
\hline $\begin{array}{c}\text { Environmental } \\
\text { paramaters }\end{array}$ & Source & $\begin{array}{c}\text { Arctic } \\
\text { database }\end{array}$ & $\begin{array}{c}\text { Tropical Atlantic } \\
\text { database }\end{array}$ & $\begin{array}{l}\text { Austral } \\
\text { database }\end{array}$ \\
\hline $\begin{array}{l}\text { Sea-Surface } \\
\text { Temperature }\end{array}$ & World Ocean Atlas & v2001 & $\begin{array}{l}\text { v2013 } \\
\text { IPSL-CM5A-LR model } \\
\text { Preindustrial simulation }\end{array}$ & v2009 \\
\hline $\begin{array}{c}\text { Sea-Surface } \\
\text { Salinity }\end{array}$ & World Ocean Atlas & v2001 & v2013 & v2009 \\
\hline $\begin{array}{l}\text { Sea-Ice } \\
\text { Cover }\end{array}$ & $\begin{array}{c}\text { National Snow and Ice } \\
\text { Data Center } \\
\text { 1953-2003 mean }\end{array}$ & $x$ & - & - \\
\hline $\begin{array}{c}\text { Primary } \\
\text { Productivity }\end{array}$ & $\begin{array}{l}\text { Vertical Generalized } \\
\text { Production Model } \\
\text { (Behrenfeld and } \\
\text { Falkowski, 1997) } \\
\text { Remote-sensing } \\
\text { spatial observations }\end{array}$ & $\begin{array}{c}\text { 2002-2005 } \\
\text { mean, Aqua- } \\
\text { Modis satellite }\end{array}$ & $\begin{array}{l}\text { 1978-2016 mean } \\
\text { CZCS-SeaWifs-Modis space } \\
\text { programs } \\
\text { IPSL-CM5A-LR model } \\
\text { Preindustrial simulation }\end{array}$ & - \\
\hline
\end{tabular}

Table 1: List of modern marine hydrological parameters implemented in modern databases and used for quantified reconstructions. 


\begin{tabular}{|c|c|c|}
\hline Code & Taxa name & Notes \\
\hline $\mathrm{ACHO}$ & Achomosphaera sp. & \\
\hline ALEX & Cf. Alexandrium tamarense cyst & \\
\hline ATAX & Ataxodinium choane & \\
\hline BSPO & Bitectatodinium spongium & \\
\hline BSPP & Brigantedinium spp. & $\begin{array}{l}\text { Sum of Brigantedinium simplex, B. cariacoense and } \\
\text { undefined Brigantedinium. }\end{array}$ \\
\hline BTEP & Bitectatodinium tepikiense & \\
\hline CYSA & Cyst Type A & \\
\hline DCHA & Dalella chathamense & \\
\hline DUBRI & Dubridinium caperatum & \\
\hline EACU & Echinidinium aculeatum & Grouped into "ECHI" in $n=237$ database \\
\hline EDEL & Echinidinium delicatum & Grouped into "ECHI" in n=237 database \\
\hline EGRA & Echinidinium granulatum & Grouped into "ECHI" in $n=237$ database \\
\hline EKAR & Echinidinium karaense & \\
\hline ETRA & Echinidinium transparentum & Grouped into "ECHI" in $n=237$ database \\
\hline ESPP & Echinidinium spp. & Grouped into "ECHI" in $n=237$ database \\
\hline ECHI & Sum of Echinidinium species & Specific to $n=237$ database \\
\hline GYMN & Gymnodinium sp. & \\
\hline IACU & Impagidinium aculeatum & \\
\hline IBRE & Islandinium brevispinosum & \\
\hline IJAP & Impagidinium japonicum & \\
\hline IMIC & Islandinium cezare & \\
\hline IMIN & Islandinium minutum & \\
\hline IPAL & Impagidinium pallidum & \\
\hline IPAR & Impagidinium paradoxum & \\
\hline
\end{tabular}




\begin{tabular}{|c|c|c|}
\hline Code & Taxa name & Notes \\
\hline IPAT & Impagidinium patulum & \\
\hline IPLI & Impagidinium plicatum & \\
\hline ISPH & Impagidinium sphaericum & \\
\hline ISTR & Impagidinium strialatum & \\
\hline IVAR & Impagidinium variaseptum & \\
\hline IVEL & Impagidinium velorum & \\
\hline LMAC & Lingulodinium machaerophorum & \\
\hline LOLI & Lejeunecysta oliva & Grouped into Lejeunecysta spp. in $n=1492$ \\
\hline LSAB & Lejeunecysta sabrina & Grouped into Lejeunecysta spp. in $n=1492$ \\
\hline NLAB & Nematosphaeropsis labyrinthus & Includes $N$. lemniscata in $\mathrm{n}=237$ database \\
\hline OAGU & Operculodinium aguinawense & \\
\hline OCEN & Operculodinium centrocarpum & \\
\hline OCSS & O. centrocarpum short processes & Split from "OCEN" only in n=1492 database \\
\hline OISR & Operculodinium israelianum & \\
\hline OJAN & Operculodinium janduchenei & \\
\hline OLON & Operculodinium longispinigerum & \\
\hline PAME & Protoperidinium americanum & \\
\hline PARC & Polykrikos sp. Arctic morphotype & \\
\hline PDAL & Cyst of Pentapharsodinium dalei & \\
\hline PERI & Protoperidinioids & \\
\hline PKOF & Polykrikos kofoidii & \\
\hline PNUD & Protoperidinium nudum & Grouped with Selenopemphix quanta in $\mathrm{n}=237$ \\
\hline PRET & Pyxidinopsis reticulata & \\
\hline PSCH & Polykrikos schwartzii & \\
\hline PZOH & Polysphaeridium zoharyi & \\
\hline
\end{tabular}




\begin{tabular}{|c|c|c|}
\hline Code & Taxa name & Notes \\
\hline QCON & Quinquecuspis concreta & \\
\hline SANT & Selenopemphix antarctica & \\
\hline SBEL & Spiniferites belerius & Grouped with Spiniferites membranaceus $(n=237)$ \\
\hline SBEN & Spiniferites bentorii & \\
\hline SBUL & Spiniferites bulloides & Grouped with Spiniferites ramosus $(n=237)$ \\
\hline SDEL & Spiniferites delicatus & \\
\hline SELO & Selenopemphix elongatus & \\
\hline SHYP & Spiniferites hyperacanthus & Grouped with Spiniferites mirabilis $(n=237)$ \\
\hline SLAZ & Spiniferites lazus & \\
\hline SMEM & Spiniferites membranaceus & \\
\hline SMIR & Spiniferites mirabilis & \\
\hline SNEP & Selenopemphix nephroides & \\
\hline SPAC & Spiniferites pachydermus & \\
\hline SQUA & Selenopemphix quanta & \\
\hline SRAM & Spiniferites ramosus & \\
\hline STEL & Stelladinium spp. & $\begin{array}{l}\text { Sum of Stelladinium stellatum, S. bifurcatus, S. } \\
\text { robustum and S. reidii }\end{array}$ \\
\hline TAPP & Trinovantedinium applanatum & \\
\hline TPEL & Tectatodinium pellitum & \\
\hline TVAN & Tuberculodinium vancampoae & \\
\hline TVAR & Trinovantedinium variabile & \\
\hline VCAL & Votadinium calvum & \\
\hline VSPI & Votadinium spinosum & \\
\hline XXAN & Xandarodinium xanthum & \\
\hline
\end{tabular}

Table 2: List of dinocyst taxa and their acronyms used in Figure 5. 